\title{
Forest Changes by Precipitation Zones in Northern China after the Three-North Shelterbelt Forest Program in China
}

\author{
Han $\mathrm{Li}^{1,2}{ }^{2}, \mathrm{Fu} \mathrm{Xu}{ }^{1}$, Zhichao $\mathrm{Li}^{2}$, Nanshan You ${ }^{2}$, Hui Zhou ${ }^{2}$, Yan Zhou ${ }^{2}$, Bangqian Chen ${ }^{3}$, Yuanwei Qin ${ }^{4}$, \\ Xiangming Xiao ${ }^{4}$ and Jinwei Dong ${ }^{2, *}$ (i) \\ 1 School of Information Science and Technology, Beijing Forestry University, Beijing 100083, China; \\ hanli@bjfu.edu.cn (H.L.); xufu@bjfu.edu.cn (F.X.) \\ 2 Key Laboratory of Land Surface Pattern and Simulation, Institute of Geographic Sciences and Natural \\ Resources Research, Chinese Academy of Sciences, Beijing 100101, China; lizc@igsnrr.ac.cn (Z.L.); \\ youns.18b@igsnrr.ac.cn (N.Y.); HuiZhou@bjfu.edu.cn (H.Z.); yanzhou152@cugb.edu.cn (Y.Z.) \\ 3 Rubber Research Institute (RRI), Chinese Academy of Tropical Agricultural Sciences (CATAS), Haikou 571101, \\ China; bqchen@catas.cn \\ 4 Department of Microbiology and Plant Biology, Center for Spatial Analysis, University of Oklahoma, \\ Norman, OK 73019-0390, USA; yuanwei.qin@ou.edu (Y.Q.); xiangming.xiao@ou.edu (X.X.) \\ * Correspondence: dongjw@igsnrr.ac.cn; Tel.: +86-10-64888827
}

Citation: Li, H.; Xu, F.; Li, Z.; You, N.; Zhou, H.; Zhou, Y.; Chen, B.; Qin, Y.; Xiao, X.; Dong, J. Forest Changes by Precipitation Zones in Northern China after the Three-North Shelterbelt Forest Program in China. Remote Sens. 2021, 13, 543. https:// doi.org/10.3390/rs13040543

Received: 18 December 2020

Accepted: 28 January 2021

Published: 3 February 2021

Publisher's Note: MDPI stays neutral with regard to jurisdictional claims in published maps and institutional affiliations.

Copyright: (c) 2021 by the authors. Licensee MDPI, Basel, Switzerland. This article is an open access article distributed under the terms and conditions of the Creative Commons Attribution (CC BY) license (https:// creativecommons.org/licenses/by/ $4.0 /)$.

\begin{abstract}
China launched the Three-North Shelterbelt Forest Program (TNSFP) in 1978 in northern China to combat desertification and dust storms, but it is still controversial in ecologically fragile arid and semi-arid areas, which is partly due to the uncertainties of monitoring of the spatial-temporal changes of forest distribution. In this study, we aim to provide an overall retrospect of the forest changes (i.e., forest gain and forest loss) in northern China during 2007-2017, and to analyze the forest changes in different precipitation zones. We first generated annual forest maps at $30 \mathrm{~m}$ spatial resolution during 2007-2017 in northern China through integrating Landsat and PALSAR/PALSAR-2 data. We found the PALSAR/Landsat-based forest maps outperform other four existing products (i.e., JAXA F/NF, FROM-GLC, GlobeLand30, and NLCD-China) from either PALSAR or Landsat data, with a higher overall accuracy $96 \% \pm 1 \%$. The spatial-temporal analyses of forests showed a substantial forest expansion from $316,898 \pm 34,537 \mathrm{~km}^{2}$ in 2007 to $384,568 \pm 35,855 \mathrm{~km}^{2}$ in 2017 in the central and eastern areas. We found a higher forest loss rate (i.e., $35 \%$ ) in the precipitation zones with the annual mean precipitation less than $400 \mathrm{~mm}$ (i.e., the arid and semi-arid areas) comparing to that (i.e., 25\%) in the zones with more than $400 \mathrm{~mm}$ (i.e., the humid areas), which suggests the lower surviving rate in the drylands. This study provides satellite-based evidence for the forest changes in different precipitation zones, and suggests that the likely impacts of precipitation on afforestation effectiveness should be considered in future implementation of ecological restoration projects like TNSFP.
\end{abstract}

Keywords: forest loss and gain; optical and SAR data integration; spatial-temporal changes; precipitation; northern China

\section{Introduction}

China has made important contributions to the world's greening pattern through afforestation and ecological engineering projects [1-3]. As the largest and most representative ecological engineering project in scale in China, the Three-North Shelterbelt Forest Program (TNSFP) was launched in northern China in 1978 in order to combat sandstorms and desertification [4-6], and northern China covers about two-thirds of Chinese arid and semi-arid regions [7]. So far, China has invested about 7129 million dollars for the TNSFP, the accumulated forestation area has reached 30 million hectares until 2018, and the rate of forest coverage has increased from 5.05\% in 1979 to $13.57 \%$ in 2018 in northern China [8].

Information on the forest distribution spatial-temporal changes is vital for forest management. Considerable studies paid attention to detecting the trends of vegetation 
in northern China to evaluate the effectiveness of the TNSFP $[6,7,9,10]$. However, the rationality of ecological engineering in ecologically fragile arid and semi-arid areas is still controversial $[5,11]$. With the progress of the TNSFP, increasingly more media outlets and studies reported the high mortality of trees [12]. Moreover, since 1949, the overall surviving rate of trees in the arid and semi-arid regions in northern China was only 15\% [13]. Until now, information on spatial-temporal changes of forests distribution in northern China is still unclear, especially in different precipitation zones in recent years. Given the great environmental impacts of ecological engineering projects in northern China, it is crucial to acquire detailed and timely information of forest gain as well as forest loss, especially in the recent period that would be helpful for decision-making in forest management and continuous implementation of the project.

Optical remote sensing images have been widely used in the generation of forest distribution maps, which include low spatial resolution images derived from Advanced Very High Resolution Radiometer (AVHRR) [14,15] and Moderate Resolution Imaging Spectroradiometer (MODIS) [16-18], and moderate spatial resolution data like Landsat TM/ETM+ images [19-22]. Although coarse spatial resolution data could reveal the spatialtemporal dynamics of forests, they have an obvious limitation in identifying small and fragmented forests patches. As the release of the USGS Landsat archive [23], Landsat data have been widely applied to generate forest maps from regional to global scale and assess forest distribution dynamics [19,20,24-26]. In comparison with AVHRR and MODIS images, the $30 \mathrm{~m}$ forest products derived from Landsat data enable capturing more specific details of the spatial-temporal dynamics of forest patches. However, due to the obstacles of clouds, fog, and cloud shadows, the usage of optical data is largely restricted by the availability and quality of observations $[27,28]$. Although the combined use of multiple years of optical data might overcome this problem, it will reduce the temporal resolution in forest dynamic monitoring [20]. Moreover, some green plants (e.g., crops with high biomass and bushes) might have similar spectral characteristics as forests. In this case, Landsat data have a high sensitivity to canopy layer characteristics, but a low sensitivity to estimation of forest structural attributes, which may have a large misclassification error [28].

Compared to optical remote sensing, active microwave remote sensing can observe land surface in almost all weather and environmental conditions [29]. The long band wavelength Synthetic Aperture Radars (SARs) (e.g., L-band) enable penetrate forest canopy and obtain detailed information on forest structure [30,31]. For example, the Phased Arraytype L-band Synthetic Aperture Radar (PALSAR) global orthorectified mosaic dataset generated by Japan Aerospace Exploration Agency (JAXA) are unaffected by the weather conditions and can provide wall-to-wall imagery covering a large area regularly [32], and have been used to monitor forest dynamics in hotspots around the world [33-35]. However, as SAR-based backscatter signals depend on the physical structure features, the SAR-based forest mapping has some limitations in identifying urban buildings, rocky landcover, and forests, as they have similar backscatter coefficient [36,37].

Several researches have shown the advantages of integrating optical and SAR images to map forests and monitor forest distribution dynamics [38,39]. Briefly, optical images offer the information of forest canopy coverage and SAR data offer information on forest physical structure (e.g., forest trunk and branch). For example, by integrating the Landsat data and PALSAR Fine Beam Dual Polarization mode (FBD) mosaic dataset, Qin et al. [38] generated annual forest maps from 2007 to 2010 in Oklahoma, and obtained the high overall accuracy and Kappa coefficient of $88.2 \%$ and 0.75 , respectively. Chen et al. [39] combined the Landsat, PALSAR, and PALSAR-2 data, and monitored the spatial-temporal dynamics of forests during 2007-2015 in Hainan, China. In northern China, the use of PALSAR/PALSAR-2 data is less affected by the terrain, as the area of mountainous terrain is relatively small in this region. Besides, Landsat data are less affected by clouds and cloud shadows because of the high latitude in this region. Therefore, there have been few researches on forest mapping by integrating the SAR data and optical data in this region. Given the success of previous studies and the natural conditions in northern China, the 
combination of optical and SAR remote sensing images might be effective for mapping forest distribution changes in this region.

In this context, our study aims to provide an overall retrospect of the forest changes (i.e., non-forest to forest and forest to non-forest) in northern China from 2007 to 2017 and attempts to address the following question: How does the forest changes (i.e., forest gain and forest loss) in different precipitation zones? It includes three parts:

- mapping forests by integrating Landsat and PALSAR/PALSAR-2 images based on a decision tree algorithm,

- $\quad$ analyzing the spatial-temporal pattern of forest gain and loss, and

- investigating the forest changes in different precipitation zones.

\section{Data and Methods}

\subsection{Study Area}

The project area of TNSFP (i.e., northern China) covers an area of 4.1 million $\mathrm{km}^{2}$ and consists of 13 provinces, accounting for about $42 \%$ of China's total land area (Figure 1). Northern China $\left(34^{\circ} 20^{\prime}-50^{\circ} 11^{\prime} \mathrm{N}\right.$ and $\left.73^{\circ} 27^{\prime}-128^{\circ} 13^{\prime} \mathrm{E}\right)$ spans about $4480 \mathrm{~km}$ from east to west, and spans about 560-1460 km from north to south. Its climate conditions (e.g., arid, semi-arid, and semi-humid) and vegetation cover types (e.g., grass, croplands, and forest) vary greatly [40]. The climate ranges from semi-humid (east) to semi-arid (middle) and arid (west). The annual mean precipitation increases from $25 \mathrm{~mm}$ in the west to $800 \mathrm{~mm}$ in the east [40]. In addition, the arid and semi-arid regions (i.e., regions with the annual mean precipitation less than $400 \mathrm{~mm}$ ) account for about $2 / 3$ of the project area.

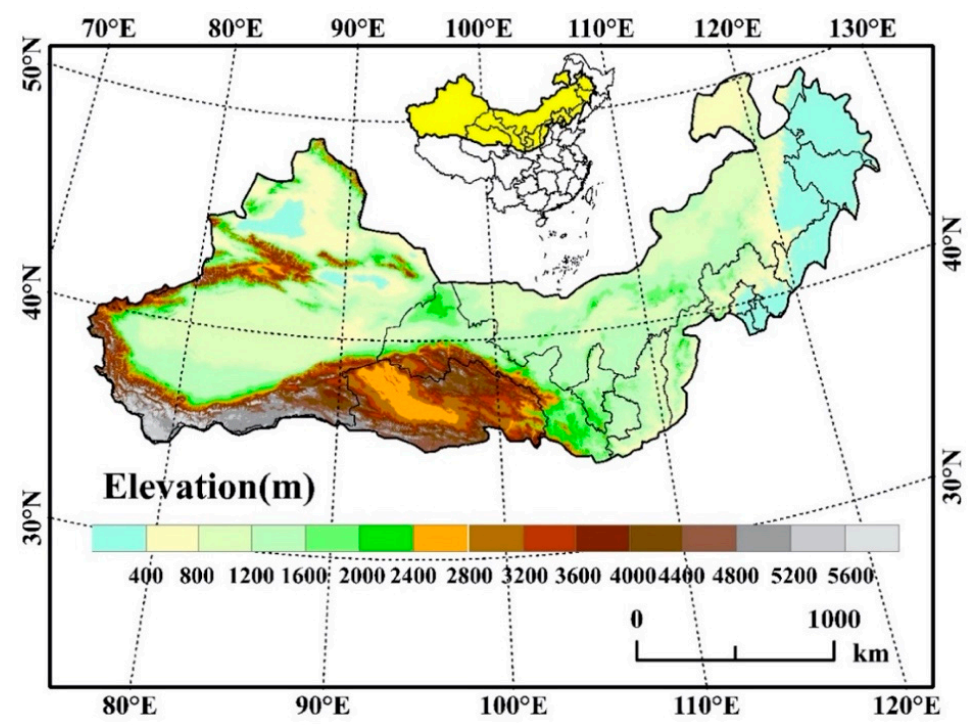

Figure 1. Location of the northern China.

\subsection{Data Collection and Preprocessing}

\subsubsection{PALSAR/PALSAR-2 Dataset and Preprocessing}

The Advanced Land Observing Satellite-1 (ALOS) PALSAR images with $25 \mathrm{~m}$ spatial resolution [32] used in this study were derived from JAXA and the Earth Observation Research Center (EORC). Polarized signals of SAR data can be transmitted and received in the horizontal or vertical dimensions through the L-band, including the transmission and reception in horizontal dimension $(\mathrm{HH})$ and the transmission in horizontal dimension and the reception in vertical dimension (HV). The PALSAR/PALSAR-2 dataset included the mosaic of $\mathrm{HH}$ and $\mathrm{HV}$ polarization data, local incidence angle, and mask information (i.e., void area, layover, effective area, ocean flag, and shadowing). By applying the $90 \mathrm{~m}$ Shuttle Radar Topography Mission (SRTM) digital elevation model (DEM), the slope correction and ortho-rectification were performed on the $\mathrm{HH}$ and $\mathrm{HV}$ backscatter data with a about 
$12 \mathrm{~m}$ geometric accuracy [41]. In this study, all the available PALSAR/PALSAR-2 HH and HV dataset from 2007 to 2017 covering the project area was used. By using the calibration coefficients from JAXA, the Digital Number (DN) values (i.e., amplitude values) in $\mathrm{HH}$ or $\mathrm{HV}$ were transformed into backscattering coefficients $\left(\gamma^{\mathrm{o}}\right)$ in decibels $(\mathrm{dB})$ as $[42,43]$

$$
\gamma^{\circ}(\mathrm{dB})=10 \log _{10} \mathrm{DN}^{2}+\mathrm{CF}
$$

where $\gamma^{\mathrm{o}}$ represents the backscattering coefficient, DN represents the digital number in $\mathrm{HH}$ and $\mathrm{HV}$, and $\mathrm{CF}$ represents the absolute calibration coefficient of -83 [43].

In addition, the Difference and Ratio layers are widely applied for classification and the calculation is as follows [34]:

$$
\begin{aligned}
\text { Difference } & =\mathrm{HH}-\mathrm{HV} \\
\text { Ratio } & =\frac{\mathrm{HH}}{\mathrm{HV}}
\end{aligned}
$$

where $\mathrm{HH}$ represents the transmission and reception in horizontal dimension, and HV represents the transmission in horizontal dimension and the reception in vertical dimension.

To match Landsat data at $30 \mathrm{~m}$ spatial resolution, the PALSAR/PALSAR-2 data (i.e., $\mathrm{HH}, \mathrm{HV}$, Difference, and Ratio layer) at $25 \mathrm{~m}$ spatial resolution were resampled to $30 \mathrm{~m}$ through the nearest neighbor method [44]. Then, we combined the preprocessed HH, HV, Difference, and Ratio and Landsat images to generate a data cube.

\subsubsection{Landsat Dataset and Preprocessing}

In this study, we used all available surface reflectance data of Landsat $5 / 7 / 8$ covering the study area from January 2007 to December 2017. The bad observations caused by clouds and cloud shadows were eliminated using the CFmask algorithm [45]. Then, almost all the pixels have good-quality observations more than 10 times from 2007 to 2017 (Figure S1) and we used to all good-quality observations to compute the Normalized Difference Vegetation Index (NDVI), and the annual maximum NDVI values (NDVI ${ }_{\max }$ ) were then calculated.

$$
\mathrm{NDVI}=\frac{\mathrm{NIR}-\mathrm{RED}}{\mathrm{NIR}+\mathrm{RED}}
$$

where NIR and RED represent the Landsat surface reflectance in the near-infrared and red bands, respectively.

\subsubsection{Precipitation Dataset and Preprocessing}

The Climate Hazards Group InfraRed Precipitation with Station data (CHIRPS) Daily data were applied in this study. The dataset incorporates satellite data at $0.05^{\circ}$ spatial resolution with in situ station data to generate gridded precipitation time series, which can provide timely and reliable precipitation data. We obtained daily precipitation data from 1 January 2007, to 1 January 2018, and calculated the annual mean precipitation from 2007 to 2017. Then, northern China was divided into five precipitation zones according to equal intervals of $200 \mathrm{~mm}$ in the annual mean precipitation range: 0-200, 200-400, 400-600, 600-800, and >800 mm (Figure 2).

\subsection{Forest Changes by Precipitation Zones in Northern China}

The overall workflow for monitoring the spatial-temporal changes of forests by precipitation zones in northern China is presented in Figure 3. It is worth noting that the forest changes mentioned in the study referred to two changes, including forest gain (i.e., the change from non-forest to forest) and forest loss (i.e., the change from forest to non-forest), but not including those within-forest changes from one type of forest to another. The overall workflow consists of four steps: (1) producing the annual forest maps (namely, PALSAR/Landsat-based forest maps) based on SAR-based metrics (i.e., HH, HV, Difference, and Ratio) and Landsat $\mathrm{NDVI}_{\max }$ time series; (2) validating the resulting forest maps 
and forest changes using ground truth samples; (3) comparing the PALSAR/Landsat-based forest maps with four existing forest maps (i.e., JAXA F/NF, FROM-GLC, GlobeLand30, and NLCD-China); and (4) investigating the forest gain, loss, and net changes and analyzing the forest changes by different precipitation zones. The detailed information is presented hereafter.

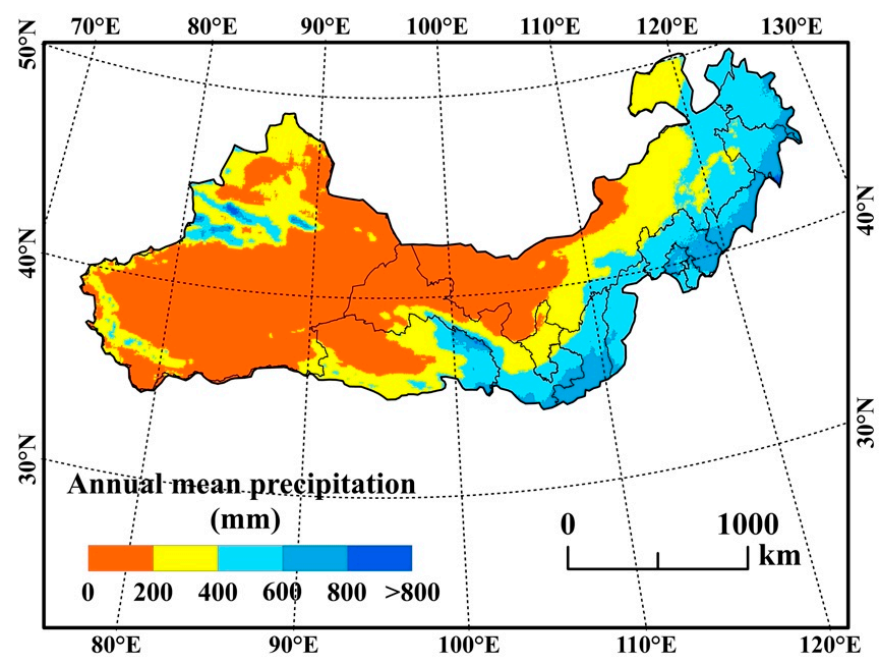

Figure 2. The five precipitation zones according to equal intervals of $200 \mathrm{~mm}$ in the annual mean precipitation in northern China from 2007 to 2017.

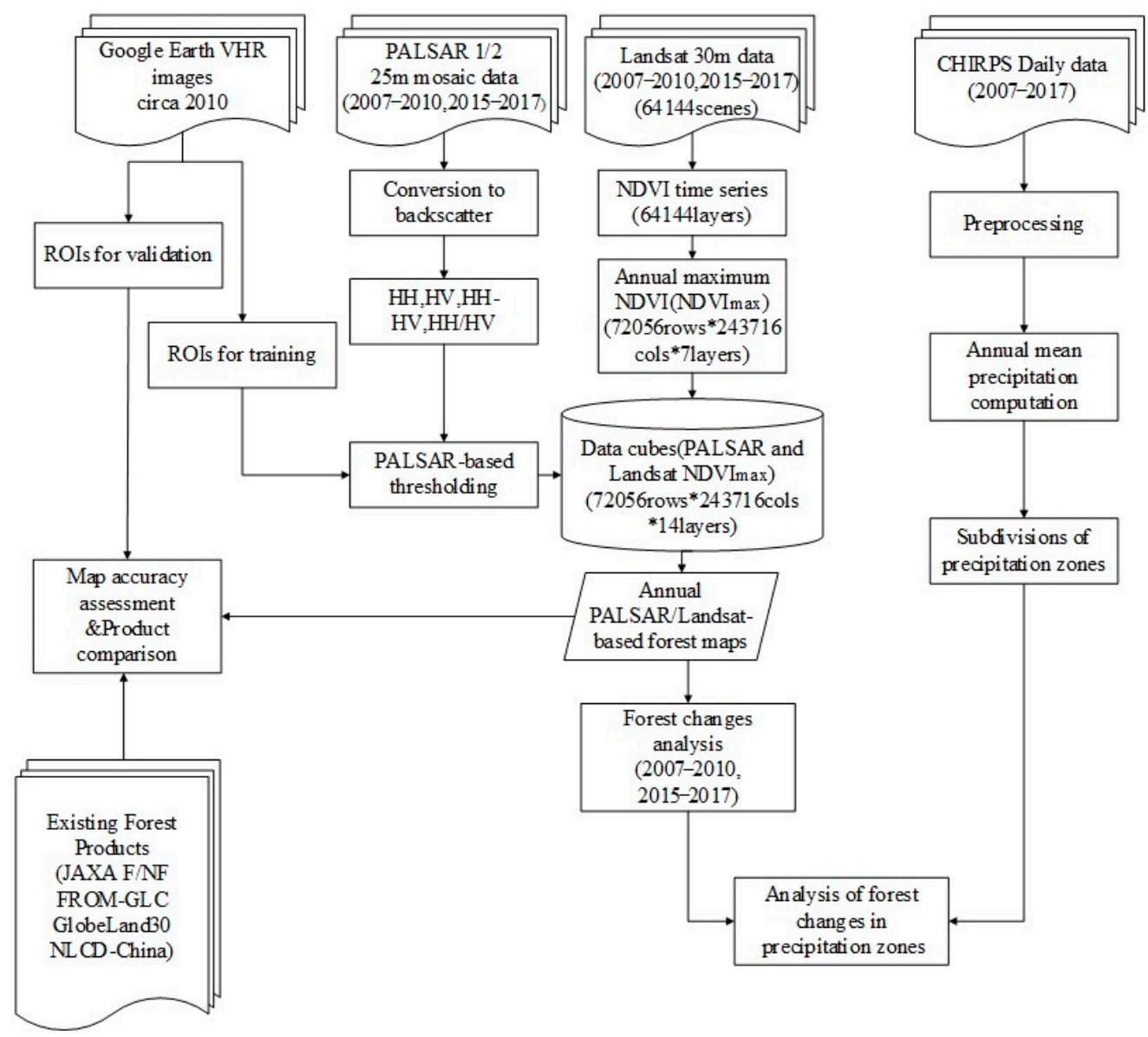

Figure 3. Summarized workflow for investigating the spatial-temporal changes of forests in different precipitation zones in northern China. 


\subsubsection{Forest mapping}

The forest definition proposed by the Food and Agriculture Organization (FAO) is a region ( $>0.5 \mathrm{ha}$ ) where tree canopy cover of $>10 \%$ and tree height of $>5 \mathrm{~m}$ [46]. Our method for monitoring the spatial-temporal changes of forests in northern China during 2007-2017 adapted this definition but did not consider the limitation of the minimum mapping unit (i.e., 0.5 ha), which involved two aspects of forests: tree height and forest canopy.

The first step is to generate the PALSAR-based forest baseline maps. Previous studies have proved that the PALSAR-based forest mapping algorithm is robust and efficient in the fragmented and fragile Loess Plateau in China [47], sparse agroforests region in the North China Plain [48], and sub-humid and semi-arid regions in Oklahoma, USA [38]. These studies applied a generalized and simple rule to identify forests (Equation (5)).

$$
(-16<\mathrm{HV}<-8) \text { AND }(2<\text { Difference }<8) \text { AND }(0.3<\text { Ratio }<0.85)
$$

In order to confirm the rationality of this rule in our study area, we collected and interpreted visually 1722 regions of interest (ROIs) for four typical land cover types (i.e., 469 samples for forest, 432 samples for cropland, 429 samples for built-up land, and 392 samples for water), and generated the histograms of HV, Difference, and Ratio for each land cover type. Then, we matched the three sets of thresholds (Equation (5)) with the histograms of backscatter coefficient of different land cover types (Figure 4) and found this rule is suitable for our study.
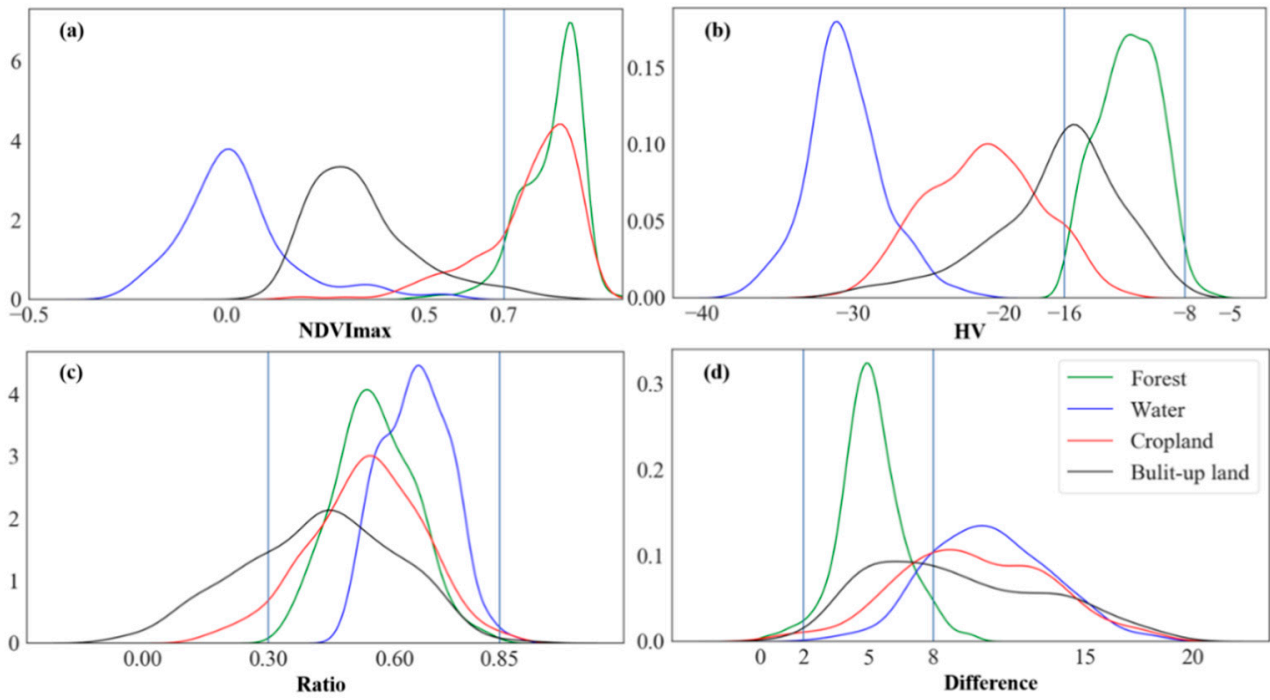

Figure 4. The annual NDVI maximum and backscatter signatures of four typical land cover types: (a) $\mathrm{NDVI}_{\max }$, (b) HV, (c) Ratio, and (d) Difference.

In the second step, we also used the above 1722 samples to generate the histograms of annual NDVI maximum (namely, $\mathrm{NDVI}_{\max }$ ) for each land cover type (Figure $4 \mathrm{a}$ ). We found that the threshold of 0.7 (Equation (6)) derived from the previous studies [38,47] is suitable for our study area. The Landsat-based NDVI $I_{\max }$ was used to mask the land cover types in PALSAR-based forest baseline maps, which have the similar backscattering coefficients with forests, such as urban buildings, farmlands, and rocky lands. Because of the high sensitivity of NDVI to forest canopy and chemical content [49], we used the $\mathrm{NDVI}_{\max }$ threshold (Equation (6)) for extracting forests and decreasing the commission errors. Finally, PALSAR-based forest layer (Equation (5)) and Landsat-based forest layer (Equation (6)) were overlaid to obtain the annual forest maps during 2007-2010 and 2015-2017.

$$
\mathrm{NDVI}_{\max }>0.7
$$




\subsubsection{Sample Collection for Accuracy Assessment of Forest Mapping and Changes}

We used the Very High Resolution (VHR) images from Google Earth (GE) and time series of inter-annual and intra-annual vegetation indices generated with Landsat and MODIS imagery in Collect Earth to evaluate the resulting forest map and forest changes from 2007 to 2017. First, the stratified random sampling method was used in this study. Following the good practices for estimating and assessing accuracy of forest change [50], we stratified the sampling according to the forest class and non-forest class in the resultant forest map of each year in our study and generated the random points by using ArcGIS software. Second, we used augmented visual interpretation to visually interpret the samples based on the VHR images in GE and time series of vegetation indices data in Collect Earth [51-53]. We discarded the samples with uncertain land cover information to ensure the reliability of the samples. Finally, we obtained 539 forests samples and 2246 non-forest samples in 2007, 542 forests samples and 2243 non-forest samples in 2008, 547 forests samples and 2238 non-forest samples in 2009, 554 forests samples and 2234 non-forest samples in 2010, 570 forests samples and 2217 non-forest samples in 2015, 571 forests samples and 2214 non-forest samples in 2016, and 573 forests samples and 2213 non-forest samples in 2017. The samples in 2010 were used for accuracy assessment and comparison of multiple forest products (Figure 5a). We adjusted the area of forest and non-forest with the corresponding confidence interval (95\%) [50].
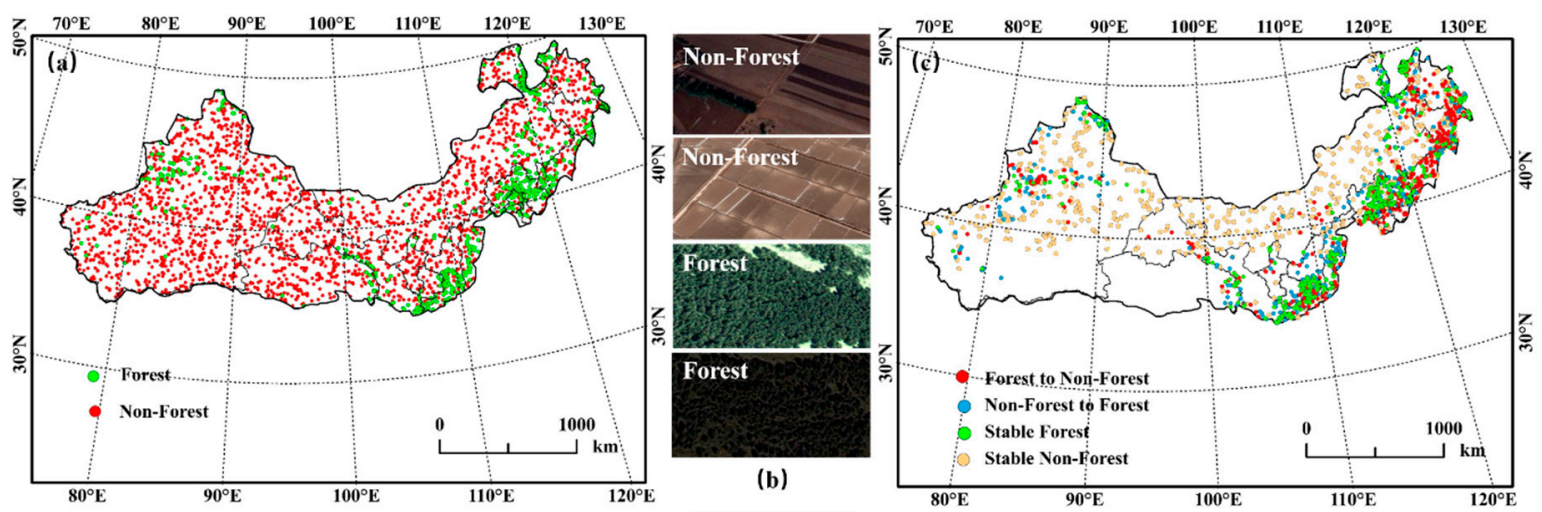

Figure 5. Spatial distribution of validation samples for accuracy assessment (a) 554 forests samples and 2234 non-forest samples in 2010. (b) Four examples of samples selected from Google Earth VHR images of 2010. (c) Four classes of samples to assess the forest changes from 2007 to 2017.

In addition, to assess the forest changes from 2007 to 2017, we conducted stratified sampling via four strata (i.e., stable forest, forest to non-forest, non-forest to forest, and stable non-forest) in the entire northern China. Then, the random samples were visually interpreted according to the VHR images from Google Earth taken circa 2007 and 2017. Finally, 558 stable non-forest samples, 334 non-forest to forest samples, 363 forest to nonforest samples, and 409 stable forest samples were obtained (Figure $5 \mathrm{c}$ ).

On the basis of the confusion matrix, the producer's accuracy (PA), user's accuracy (UA), and overall accuracy (OA) were computed and adjusted by a $95 \%$ confidence interval to evaluate the annual forest maps from 2007 to 2017 and the forest change map from 2007 to 2017.

\subsubsection{Comparison of Multiple Forest Products in Northern China and} Accuracy Assessment

We selected four forest products at relatively high spatial resolutions in 2010, and qualitatively and quantitatively compared them with our forest maps in northern China to assess the performance of our products, including (1) JAXA FNF forest map [32], (2) FROMGLC forest map [54], (3) GlobeLand30 forest map [55], and (4) NLCD-China forest map [56] (Table 1). Based on the samples in Figure 5a, we first computed the PA, UA, OA, and Kappa 
coefficient to assess the accuracy of the five forest maps using the confusion matrix method and adjusted the accuracy assessment by a 95\% confidence interval [50]. We also evaluated our forest map by computing a consistency index between our forest map and each of the other four products. The consistency index refers to the ratio of the number of mutual forest (or non-forest) samples to the total number of forest (or non-forest) samples in Figure 5a. Moreover, we visually compared the forest spatial details among these forest maps.

Table 1. Summary information of forest products in northern China in 2010.

\begin{tabular}{|c|c|c|c|c|c|}
\hline Forest Products & Forest Definition & $\begin{array}{c}\text { Spatial } \\
\text { Resolution }\end{array}$ & $\begin{array}{l}\text { Classification } \\
\text { Algorithms }\end{array}$ & Data Resources & References \\
\hline JAXA F/NF & $\begin{array}{c}\text { Tree height } \geq 5 \mathrm{~m} \\
\text { Canopy cover } \geq 10 \%\end{array}$ & $25 \mathrm{~m}$ & Decision Tree & PALSAR & [32] \\
\hline FROM-GLC & $\begin{array}{c}\text { Tree height } \geq 3 \mathrm{~m} \\
\text { Canopy cover } \geq 15 \%\end{array}$ & $30 \mathrm{~m}$ & $\begin{array}{c}\text { Supervised } \\
\text { Classification }\end{array}$ & Landsat & [54] \\
\hline Globe Land30 & Canopy cover $\geq 10 \%$ & $30 \mathrm{~m}$ & $\begin{array}{l}\text { Pixel-Object- } \\
\text { Knowledge } \\
\text { (POK)-based } \\
\text { approach }\end{array}$ & $\begin{array}{l}\text { Landsat, } \\
\text { HJ-1 }\end{array}$ & [55] \\
\hline NLCD-China & Canopy cover $\geq 10 \%$ & $100 \mathrm{~m}$ & $\begin{array}{c}\text { Visual interpretation } \\
\text { approach }\end{array}$ & $\begin{array}{c}\text { Landsat, CBERS, } \\
\text { HJ-1 } \\
\text { and } \mathrm{HJ}-1 \mathrm{~A}\end{array}$ & [56] \\
\hline $\begin{array}{l}\text { PALSAR/Landsat- } \\
\text { based } \\
\text { map }\end{array}$ & $\begin{array}{c}\text { Tree height } \geq 5 \mathrm{~m} \\
\text { Canopy cover } \geq 10 \%\end{array}$ & $30 \mathrm{~m}$ & Decision Tree & $\begin{array}{c}\text { PALSAR/PALSAR-2, } \\
\text { Landsat }\end{array}$ & This study \\
\hline
\end{tabular}

\subsubsection{Forest Cover Changes Analysis in Different Precipitation Zones}

To understand the forest changes in different precipitation zones in northern China, we first overlapped the forest maps in 2007 and 2017, and generated the map of forest dynamics consisting of stable forest, non-forest to forest, forest to non-forest, and stable non-forest. Here, forest loss refers to the change at pixel level from forest in 2007 to nonforest in 2017, and forest gain refers to the change at pixel level from non-forest in 2007 to forest in 2017. Then, the study area was divided into five precipitation zones (Figure 2). We also simply divided the region into two zones according to the threshold of $400 \mathrm{~mm}$ annual mean precipitation, i.e., semi-arid and semi-humid zones. A total of seven precipitation zones were generated, including 0-200, 200-400, 400-600, 600-800, >800, 0-400, and >400. Finally, for each precipitation zone, we computed the area of the forest in 2007, forest in 2017, forest gain, and forest loss.

Furthermore, to investigate the statistical relationship between precipitation and forest loss in northern China during 2007-2017, we used the finer interval in the annual mean precipitation range (i.e., $20 \mathrm{~mm}$ ) and generated 43 precipitation zones. We overlapped the ratio of forest loss (i.e., forest loss from 2007-2017 divided by forest in 2007) with the 43 precipitation zones, and analyzed the variation in the ratio of forest loss along the precipitation gradients. In addition, a linear least-squares regression with 43 observations of the ratio of forest loss vs. the annual mean precipitation in the period 2007-2017 was performed.

\section{Results}

3.1. Accuracy Analysis of PALSAR/Landsat-Based Forest Map of Northern China and Comparison with Other Four Forest Maps

Results of the accuracy assessment of the five forest products in 2010 are presented in Table 2. We provided the complete confusion matrixes for the PALSAR/Landsatbased forest map and other four forest products in 2010 (Tables S1-S5). Clearly, the 
PALSAR/Landsat-based forest map had the highest OA and Kappa coefficient $(96 \% \pm 1 \%$ and 0.66 , respectively). The OA of the other four forest products is similar, ranging from $87 \%$ to $89 \%$. Although all forest maps had high OA (i.e., more than $80 \%$ ), the PA of the forest indicated a larger difference and that of the non-forest class a smaller difference. Specifically, for the forest class, the PA of PALSAR/Landsat-based forest map in this study was $56 \% \pm 6 \%$, while that in other forest maps was less than $31 \%$. That meant the omission error of other forest maps in the study area was far higher than the PALSAR/Landsat-based forest map. In addition to the NLCD forest map, the UAs of the forest class in other forest maps were greater than $80 \%$. The UA of our result was $80 \% \pm 3 \%$. That meant there would be some commission errors in both our results and the NLCD forest maps. Spatial consistency analyses based on the samples showed that the highest spatial consistency index of forest is presented between the PALSAR/Landsat-based and FROM-GLC forest maps (50.54\%), while the lowest spatial consistency index of the forest is shown between PALSAR/Landsat-based and JAXA F/NF forest maps (44.40\%).

Table 2. Accuracy assessment and consistency of PALSAR/Landsat-based map and the other four forest products in 2010. The consistency refers to the ratio of the number of mutual forest (or nonforest) samples to the total number of forest (or non-forest) samples in Figure 5a. Accuracy measures are adjusted and presented by a $95 \%$ confidence interval.

\begin{tabular}{|c|c|c|c|c|c|c|}
\hline Forest Products & $\begin{array}{l}\text { Land } \\
\text { Cover } \\
\text { Types }\end{array}$ & UA & PA & OA & Kappa & Consistency \\
\hline PALSAR/Landsat & $\begin{array}{c}\text { Forest } \\
\text { Non- } \\
\text { Forest }\end{array}$ & $\begin{array}{l}80 \% \pm 3 \% \\
97 \% \pm 1 \%\end{array}$ & $\begin{array}{l}56 \% \pm 6 \% \\
99 \% \pm 0 \%\end{array}$ & $96 \% \pm 1 \%$ & 0.66 & - \\
\hline GlobeLand30 & $\begin{array}{c}\text { Forest } \\
\text { Non- } \\
\text { Forest }\end{array}$ & $\begin{array}{l}88 \% \pm 3 \% \\
90 \% \pm 1 \%\end{array}$ & $\begin{array}{l}31 \% \pm 3 \% \\
99 \% \pm 0 \%\end{array}$ & $89 \% \pm 1 \%$ & 0.43 & $\begin{array}{l}47.47 \% \\
93.06 \%\end{array}$ \\
\hline FROM-GLC & $\begin{array}{c}\text { Forest } \\
\text { Non- } \\
\text { Forest }\end{array}$ & $\begin{array}{l}87 \% \pm 3 \% \\
89 \% \pm 1 \%\end{array}$ & $\begin{array}{l}30 \% \pm 3 \% \\
99 \% \pm 0 \%\end{array}$ & $89 \% \pm 1 \%$ & 0.42 & $\begin{array}{l}50.54 \% \\
93.38 \%\end{array}$ \\
\hline NLCD-China & $\begin{array}{c}\text { Forest } \\
\text { Non- } \\
\text { Forest }\end{array}$ & $\begin{array}{l}77 \% \pm 4 \% \\
89 \% \pm 1 \%\end{array}$ & $\begin{array}{l}28 \% \pm 3 \% \\
98 \% \pm 0 \%\end{array}$ & $89 \% \pm 1 \%$ & 0.37 & $\begin{array}{l}46.28 \% \\
93.27 \%\end{array}$ \\
\hline JAXA F/NF & $\begin{array}{c}\text { Forest } \\
\text { Non- } \\
\text { Forest }\end{array}$ & $\begin{array}{l}84 \% \pm 3 \% \\
87 \% \pm 1 \%\end{array}$ & $\begin{array}{l}26 \% \pm 2 \% \\
99 \% \pm 0 \%\end{array}$ & $87 \% \pm 1 \%$ & 0.29 & $\begin{array}{l}44.40 \% \\
93.64 \%\end{array}$ \\
\hline
\end{tabular}

UA: user's accuracy, PA: producer's accuracy, OA: overall accuracy.

Figure 6 presents the forest spatial distribution in northern China in 2010 derived from the five forest products. In general, the forest spatial distribution is similar, and most of forest patches are distributed in the southern and eastern areas of northern China. Figure 7 presents a visual comparison between the Google Earth image and the five forest products. Although the overview of the forest spatial distribution was similar (Figure 6), there are evident differences in small forest patches or fragmented forest areas. For example, in the case of Subarea A, the forests observed in the JAXA F/NF, NLCD-China, and FROM-GLC forest maps were very few. In contrast, the PALSAR/Landsat-based map and GlobeLand30 forest map showed more details of forest dispersion that were more similar with Google Earth image. In the case of Subarea B, the forests were not observed by JAXA F/NF forest map, and some forest details were ignored in the NLCD-China, FROM-GLC, and GlobeLand 30 forest maps. Moreover, in the case of Subarea C, arrayed forest patches in urban area were not captured in NLCD-China, FROM-GLC, and GlobeLand30 forest maps, and the JAVA F/NF forest map cannot correctly identify the forest distribution. Overall, JAXA F/NF, NLCD-China, FROM-GLC, and GlobeLand30 missed more information of forest distribution, especially in areas with high forest fragmentation. Compared with them, PALSAR/Landsat-based forest map was most similar with Google Earth image. 

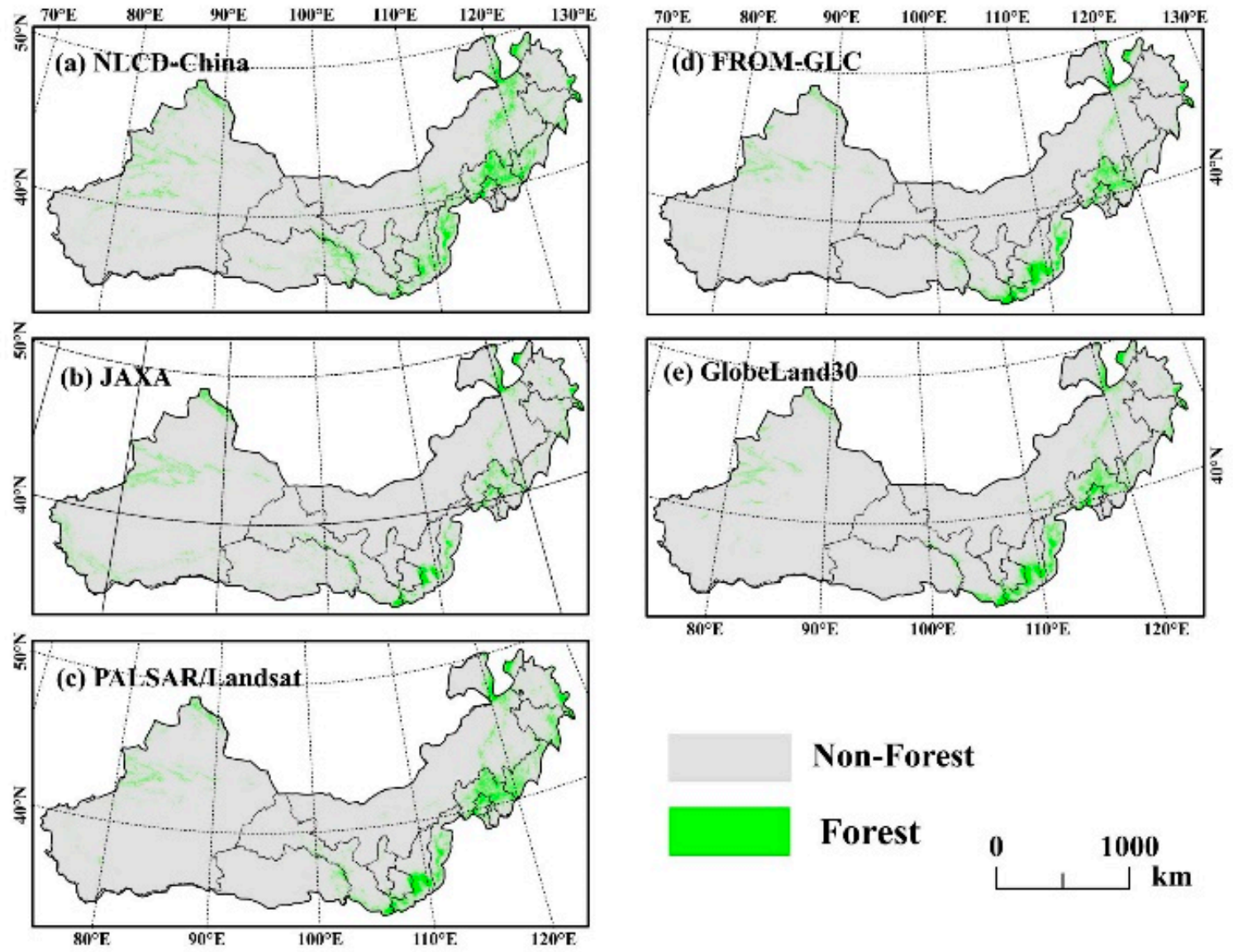

Figure 6. Forest spatial distribution derived from the PALSAR/Landsat-based forest map and other four forest products in 2010. (a) NLCD-China forest map; (b) JAXA FNF forest map; (c) PALSAR/Landsat-based forest map; (d) FROM-GLC forest map; (e) GlobeLand30 forest map.

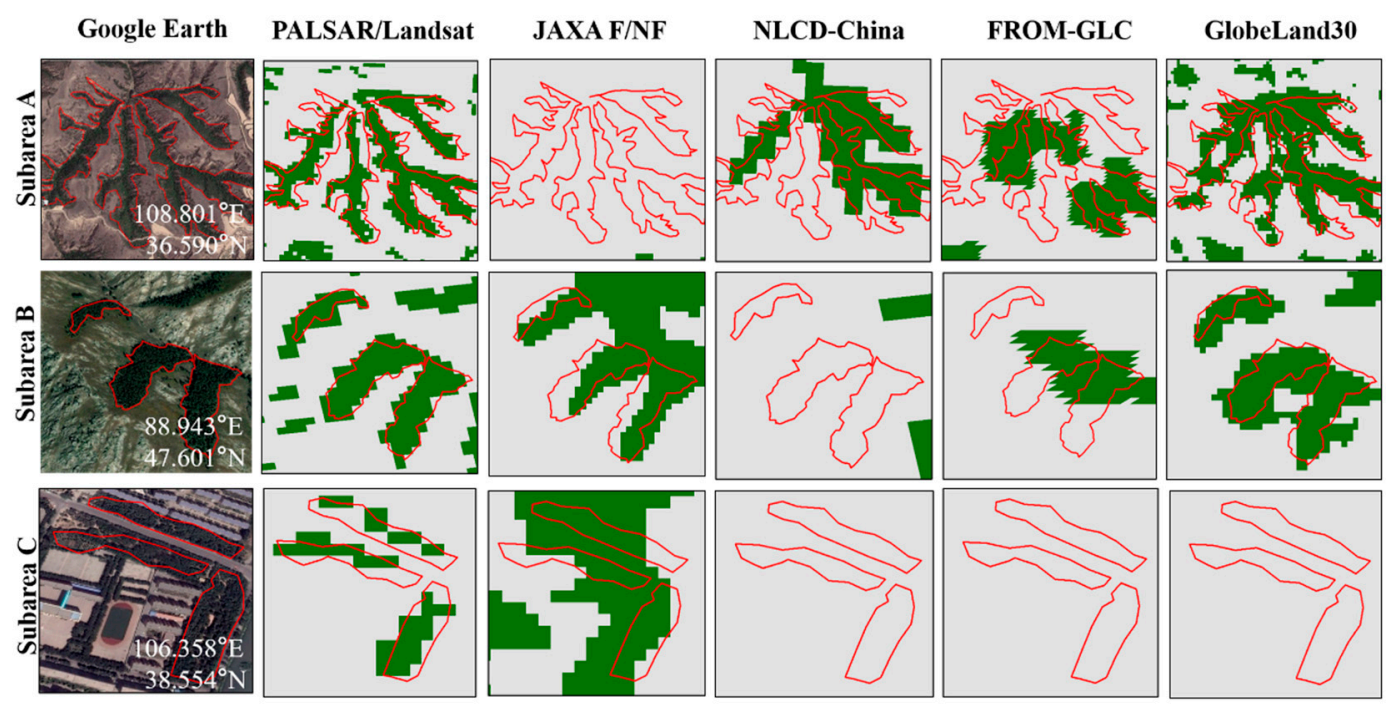

Figure 7. Qualitative comparison between VHR images in Google Earth, PALSAR/Landsat-based forest map, and the other four forest products in three randomly chose subareas. The red polygons represent the forest patches interpreted visually based on Google Earth. The coordinates refer to the center of the subareas. Subarea A: $2.25 \mathrm{~km}^{2}$, Subarea B: $0.50 \mathrm{~km}{ }^{2}$, Subarea C: $0.11 \mathrm{~km}^{2}$. 


\subsection{Areal Changes of PALSAR/Landsat-Based Forest Map}

Based on the resulting forest maps in this study, the total forest areas in northern China were $316.89 \pm 34.54,331.12 \pm 34.67,340.58 \pm 35.58,290.24 \pm 29.20,396.68 \pm 37.95$, $404.50 \pm 37.45$, and $384.57 \pm 35.86$ thousand $\mathrm{km}^{2}$ in 2007, 2008, 2009, 2010, 2015, 2016, and 2017, respectively (Figure 8). The averaged forest area during 2015-2017 (395.25 thousand $\mathrm{km}^{2}$ ) was higher than that during 2007-2010 (319.71 thousand $\mathrm{km}^{2}$ ) (Figure 8). It is worth noting a remarkable decrease in the forest area of 2010, which could be related the rapid urban and industrial expansion [57]. In the 2015-2017 period, the forest area in 2016 peaked with a subsequent decrease in 2017. Moreover, the forest area in 2017 was smaller than that in 2015. We study the spatial distribution of forest gain, forest loss, stable forest, and stable non-forest between 2015 and 2017(Figure S2). Forest loss (2015-2017) occurred mainly in Northeast China. Northeast China is the most important wood production region and industrial area in China, so large-scale logging of trees for wood. Such a fact might not imply that part of the afforestation has been unsuccessful as the Three-North Shelterbelt Forest Program pays attention to the afforestation effect of the entire northern China.

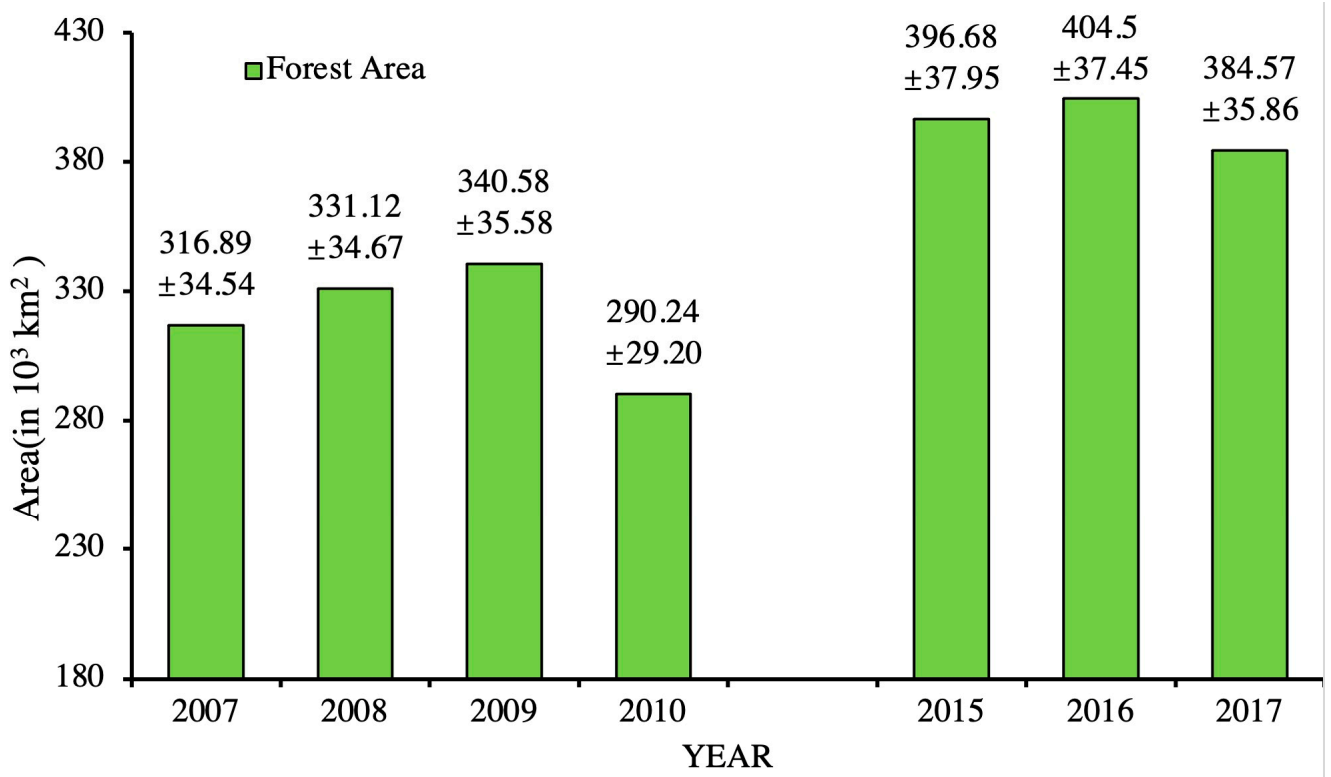

Figure 8. Forest area variation in northern China from 2007 to 2017. The forest area from 2007 to 2017 was adjusted based confusion matrix by $95 \%$ confidence intervals.

\subsection{Forest Spatial Changes during 2007-2017}

3.3.1. Accuracy Assessment of Forest Spatial Changes during 2007-2017

According to the four types of samples in Figure 5c, we assessed the accuracy of forest changes from 2007 to 2017. The results showed that the high OA and Kappa value of forest changes were $98 \% \pm 1 \%$ and 0.97 , respectively (Table 3). The PA and UA of the four classes (i.e., Non-Forest to Forest, Forest to Non-Forest, stable forest and stable non-forest) are more than 70\%. The overall result of forest changes from 2007 to 2017 was highly consistent with the real land cover change random samples. 
Table 3. Confusion matrix for the forest change map from 2007 to 2017.Class 1 is Non-Forest to Forest, class 2 is Forest to Non-Forest, class 3 is stable forest, and class 4 is stable non-forest. Accuracy measures are presented with a $95 \%$ confidence interval.

\begin{tabular}{cccccccccc}
\hline & & \multicolumn{10}{c}{ Reference } \\
\cline { 3 - 9 } & & $\mathbf{1}$ & $\mathbf{2}$ & $\mathbf{3}$ & $\mathbf{4}$ & $\mathbf{W i}$ & $\mathbf{U A}$ & PA & OA \\
\hline \multirow{4}{*}{ Map } & 1 & 317 & 4 & 18 & 86 & 0.03 & $75 \% \pm 5 \%$ & $74 \% \pm 18 \%$ & $98 \% \pm 1 \%$ \\
& 2 & 4 & 356 & 20 & 51 & 0.01 & $83 \% \pm 4 \%$ & $80 \% \pm 8 \%$ & \\
& 3 & 11 & 2 & 370 & 47 & 0.04 & $86 \% \pm 3 \%$ & $89 \% \pm 9 \%$ & \\
& 4 & 2 & 1 & 1 & 374 & 0.92 & $98 \% \pm 1 \%$ & $99 \% \pm 0 \%$ & \\
& Total & 334 & 363 & 409 & 558 & & & & \\
\end{tabular}

UA: user's accuracy, PA: producer's accuracy, OA: overall accuracy.

\subsubsection{Forest Spatial Changes during 2007-2017}

In our study, we generated the annual forests maps in the northern China during 2007-2010 and 2015-2017 (Figure S3). Most of the forests were distributed in the eastern part of the region, such as Shaanxi Province, Shanxi Province, and the Beijing-Tianjin-Hebei region. There were few forest patches in the central and western regions.

The spatial distribution of forest gain, forest loss, stable forest, and stable non-forest between 2007 and 2017 was shown in Figure 9. Most of the forest area (73.67\%) did not change from 2007 to 2017 . Those stable forests were mainly distributed in the east and south of the study area, such as southern Shaanxi Province, central Shanxi Province, central Hebei Province, Beijing, and the eastern part of the northeast region, where the climate was humid and suitable for tree growth. The forest loss occurred mainly in Northeast China, including Heilongjiang, Jilin, and Liaoning, whereas the forest gain was mainly occurred in northern Shaanxi, Shanxi, the Beijing-Tianjin-Hebei region, and Jilin.
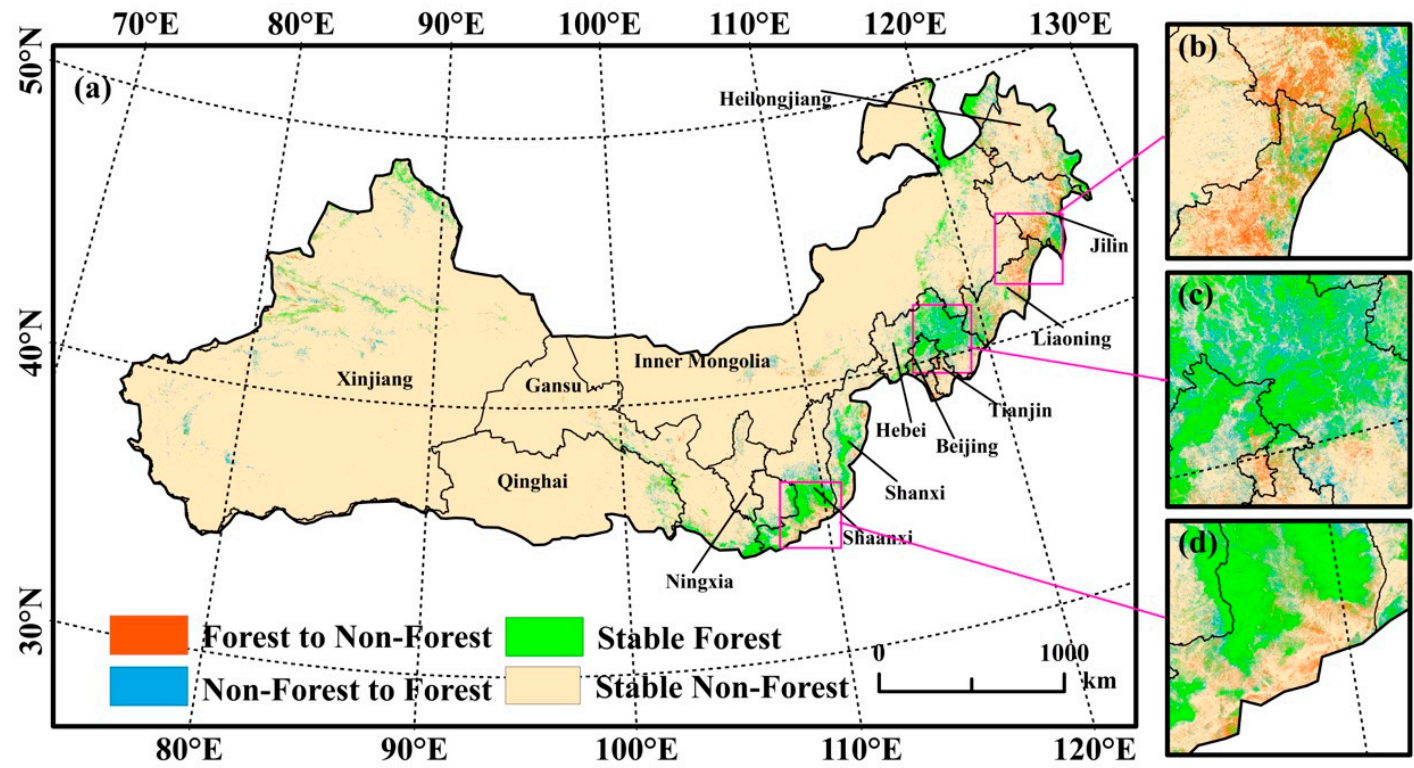

Figure 9. Spatial distribution of forest gain, forest loss, stable forest and stable non-forest in northern China (a) and three selected sub-areas (b-d) from 2007 to 2017.

\subsection{Forest Changes by Different Precipitation Zones during 2007-2017}

Figure 10 and Table 4 presented the forest area and forest changes in different precipitation zones in northern China. We computed the ratio of forest area in different precipitation zones to the forest area in entire study area. For 2007 and 2017, 89\% and 86\% forests were located in the areas with annual mean precipitation ranging from $400 \mathrm{~mm}$ to $800 \mathrm{~mm}$, respectively. Forest gain occurred in each precipitation zone (Figure 10h-n and Table 4). 
We found that forest gain proportion in the humid areas $(8.06 \%$, Table 4, Figure $10 \mathrm{~m}, \mathrm{n})$ is higher than that in the arid and semi-arid areas $(0.70 \%)$. Moreover, the forest loss in northern China could not be ignored (Figure 10a-g and Table 4). For example, more than $22 \%$ of forest in 2007 was lost in the entire study area (Figure 10a-e), and the highest percent occurred in the zone with annual mean precipitation less than $200 \mathrm{~mm}$ (i.e., $41.91 \%$ ) (Figure 10a). It is worth noting that the forest loss proportion was $35.01 \%$ in the zone with annual mean precipitation less than $400 \mathrm{~mm}$ (i.e., the arid and semi-arid areas in northern China) (Figure 10).
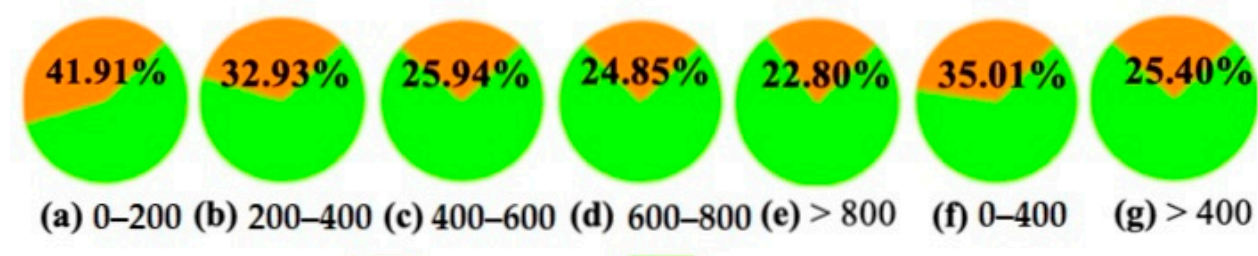

\section{Forest Loss}

(d) $600-800$ (e) $>800$

(f) 0-400

(g) $>400$
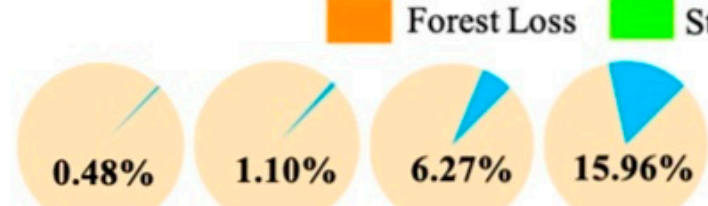

Stable Forest

(h) 0-200

(i) $200-4$

0 (j)

\section{Forest Gain}

(k) $600-800$ (l) $>800$

(m) $0-400$

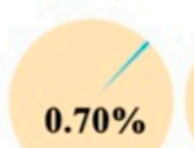

$8.06 \%$

Figure 10. Forest changes (loss and gain) in different precipitation zones from 2007 to 2017. (a-g) The ratio of forest loss (2007-2017) in the original forest area (2007) of different precipitation zones. (h-n) The ratio of forest gain (2007-2017) in the original non-forest area (2007) of different precipitation zones.

Table 4. Forest area (in $\mathrm{km}^{2}$ ) in 2007 and forest changes in different precipitation zones in northern China from 2007 to 2017. Note that confidence intervals of areal estimates (and derived rates) were not calculated in this table due to the unavailability of sufficiently covered ground truth data in all the strata in each precipitation zone in both 2007 and 2017.

\begin{tabular}{|c|c|c|c|c|c|c|c|}
\hline & $0-200 \mathrm{~mm}$ & $200-400 \mathrm{~mm}$ & $400-600 \mathrm{~mm}$ & $600-800 \mathrm{~mm}$ & $>800 \mathrm{~mm}$ & $0-400 \mathrm{~mm}$ & $>400 \mathrm{~mm}$ \\
\hline Total area & $1,873,238$ & $1,027,372$ & 844,123 & 255,323 & 6649 & $2,900,611$ & $1,106,096$ \\
\hline $\begin{array}{l}\text { Forest in } 2007 \\
\text { (percentage }^{1} \text { ) }\end{array}$ & $\begin{array}{c}4818 \\
(0.26 \%)\end{array}$ & $\begin{array}{l}15,985 \\
(1.56 \%)\end{array}$ & $\begin{array}{c}99,704 \\
(11.81 \%)\end{array}$ & $\begin{array}{c}87,356 \\
(34.21 \%)\end{array}$ & $\begin{array}{c}2181 \\
(32.80 \%)\end{array}$ & $\begin{array}{l}20,803 \\
(0.72 \%)\end{array}$ & $\begin{array}{l}189,241 \\
(17.11 \%)\end{array}$ \\
\hline $\begin{array}{l}\text { Forest in } 2017 \\
\left(\text { percentage }{ }^{2} \text { ) }\right.\end{array}$ & $\begin{array}{c}11,718 \\
(0.63 \%)\end{array}$ & $\begin{array}{l}21,865 \\
(2.13 \%)\end{array}$ & $\begin{array}{c}120,525 \\
(14.28 \%)\end{array}$ & $\begin{array}{c}92,458 \\
(36.21 \%)\end{array}$ & $\begin{array}{c}2114 \\
(31.79 \%)\end{array}$ & $\begin{array}{c}33,583 \\
(1.16 \%)\end{array}$ & $\begin{array}{l}215,097 \\
(19.45 \%)\end{array}$ \\
\hline $\begin{array}{c}\text { Forest gain } \\
\left(\text { percentage }^{3} \text { ) }\right.\end{array}$ & $\begin{array}{c}8919 \\
(0.48 \%)\end{array}$ & $\begin{array}{c}11,144 \\
(1.10 \%)\end{array}$ & $\begin{array}{c}46,683 \\
(6.27 \%)\end{array}$ & $\begin{array}{c}26,810 \\
(15.96 \%)\end{array}$ & $\begin{array}{c}431 \\
(9.65 \%)\end{array}$ & $\begin{array}{c}20,063 \\
(0.70 \%)\end{array}$ & $\begin{array}{c}73,924 \\
(8.06 \%)\end{array}$ \\
\hline $\begin{array}{c}\text { Forest loss } \\
(\text { percentage } \\
{ }^{4} \text { ) }\end{array}$ & $\begin{array}{c}2019 \\
(41.91 \%)\end{array}$ & $\begin{array}{c}5263 \\
(32.93 \%)\end{array}$ & $\begin{array}{c}25,862 \\
(25.94 \%)\end{array}$ & $\begin{array}{l}21,708 \\
(24.85 \%)\end{array}$ & $\begin{array}{c}497 \\
(22.80 \%)\end{array}$ & $\begin{array}{c}7283 \\
(35.01 \%)\end{array}$ & $\begin{array}{c}48,067 \\
(25.40 \%)\end{array}$ \\
\hline $\begin{array}{c}\text { Net change } \\
\left(\text { percentage }^{5}\right)\end{array}$ & $\begin{array}{c}6899 \\
(143.19 \%)\end{array}$ & $\begin{array}{c}5880 \\
(36.78 \%)\end{array}$ & $\begin{array}{c}20,820 \\
(20.88 \%)\end{array}$ & $\begin{array}{c}5102 \\
(5.84 \%)\end{array}$ & $\begin{array}{c}-66 \\
(3.03 \%)\end{array}$ & $\begin{array}{c}12,780 \\
(61.43 \%)\end{array}$ & $\begin{array}{c}8919 \\
(4.71 \%)\end{array}$ \\
\hline
\end{tabular}

1 The percentage refers to the ratio of forest area in 2007 to the total area of each precipitation zone. ${ }^{2}$ The percentage refers to the ratio of forest area in 2017 to the total area of each precipitation zone. ${ }^{3}$ The percentage refers to the ratio of forest gain area to the non-forest area in 2007 of each precipitation zone. ${ }^{4}$ The percentage refers to the ratio of forest loss area to the forest area in 2007 of each precipitation zone. ${ }^{5}$ The percentage refers to the ratio of net change area to the forest area in 2007 of each precipitation zone.

Moreover, a significant negative relationship between the ratio of forest loss and annual mean precipitation was found, with the slope of $0.03 \% / \mathrm{mm}$ ( $p$-value $<0.01$ and $\mathrm{R}^{2}=0.47$ ) (Figure 11). That is to say, the forest loss proportion decreased from more arid zones towards more humid zones. 


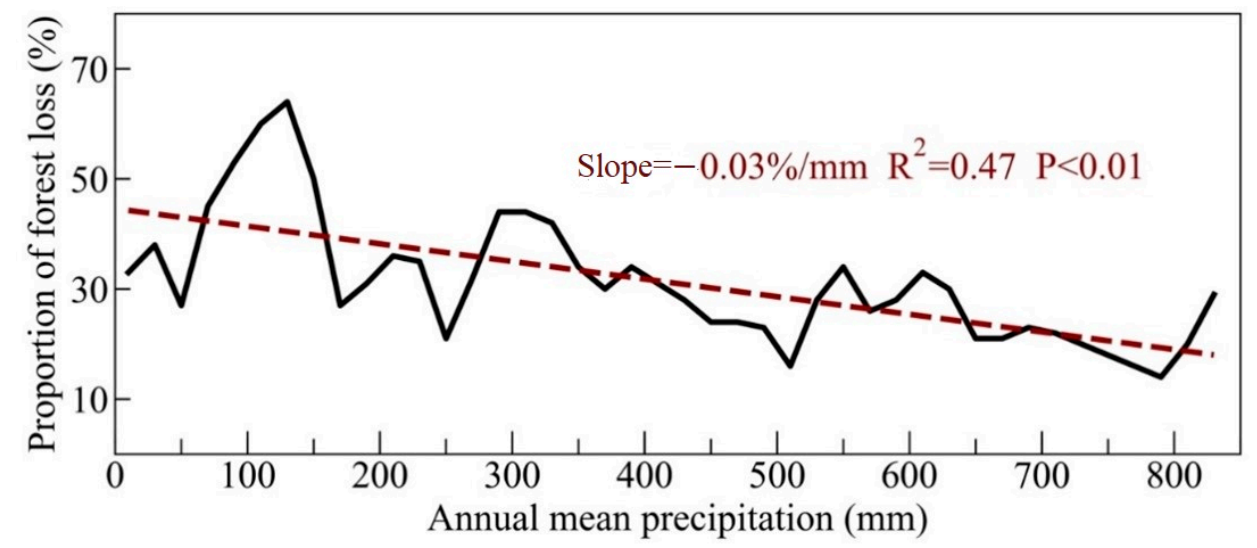

Figure 11. The linear regression analysis between the annual precipitation and the ratio of forest loss.

\section{Discussion}

\subsection{Forest Mapping Based on PALSAR and Landsat Data Integration in Northern China}

In our study, annual forest maps (namely, PALSAR/Landsat-based forest maps in this study) of northern China with high OA and Kappa coefficient (Table 2) during 2007-2017 were generated, by integrating the Landsat and PALSAR/PALSAR-2 data. Compared with the other existing forest products based solely on optical data (i.e., GlobeLand30, NLCD-China, and FROM-GLC) and SAR data (i.e., JAXA F/NF), PALSAR/Landsat-based forest maps could capture more details of forest pattern that is closest to the actual situation (Figure 7). Integrating PALSAR/PALSAR-2 and Landsat data is suitable for forest mapping in northern China that could be explained by the following facts.

First, the forest definition plays a critical part in forest mapping [52], and different forest products often used different standards in terms of forest coverage and tree height [58]. Integrating SAR and optical data allows providing two types of information. In our study, we took into account both tree height and forest canopy cover and integrated the PALSAR and Landsat data for forest mapping. Our study adopted the forest definition of FAO

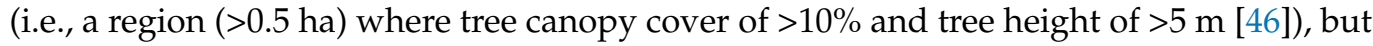
did not consider the limitation of the minimum mapping unit ( $0.5 \mathrm{ha})$. The JAXA F/NF forest product adopted the same forest definition used in our study, but solely used SAR data [32]. The forest definition used by the FROM-GLC forest map is tree canopy coverage over $15 \%$ and tree height over $3 \mathrm{~m}$, but the land cover mapping is purely based on optical data [54]. Moreover, the NLCD-China forest product and GlobeLand30 forest product adopted a looser criteria of forest definition: forest canopy coverage over $10 \%$, regarding to the limitations of optical data $[55,56]$.

Second, integrating PALSAR/PALSAR-2 and Landsat data captured not only structure information, but also spectral information, which effectively reduced the omission error. In fact, mapping forest maps based on Landsat data is susceptible to clouds and cloud shadows [27], and crops with high biomass and shrubs with high greenness probably have spectral signatures similar to forest, which cannot be distinguished from the forest by optical data [28]. PALSAR/PALSAR-2 data are susceptible to the terrain and soil moisture [32]. Moreover, the SAR-based forest maps rely on the physical structure, and there have certain limitations in classification due to similar backscattering coefficients between urban buildings and forests [36,37]. The UA of PALSAR/Landsat-based forest map was relatively low. This may be the reason for the quality of PALSAR/PALSAR-2 data. The temporal interval of the PALSAR/PALSAR-2 mosaic is generally one year and the PALSAR data have a big gap in the rainy or dry season. In future, we will consider optical and microwave remote sensing data with finer temporal and spatial resolution or determine the thresholds with the histograms of backscatter coefficient by different region.

Finally, the geolocation and terrain features of the study area are two important reasons for integrating Landsat and PALSAR/PALSAR-2 data in forest mapping in northern China. In this region, Landsat data are less affected by clouds and cloud shadows due to the high 
latitude, and PALSAR/PALSAR-2 data is less affected by the terrain because of relatively small area of mountainous terrain.

\subsection{Forest Gain and Loss in Northern China during 2007-2017}

Although information on the actual polygons and dates of afforested areas is crucial to assess afforestation effectiveness of TNSFP, unfortunately we could not get access to the vector polygon data for afforestation especially the TNSFP. In our study, we investigated spatial-temporal changes of forest distribution (i.e., forest gain and forest loss) in northern China. The results could provide detailed and timely forest cover information in a recent period and that were likely related to the TNSFP activity, which were helpful for decisionmaking in forest management and continuous implementation of the project.

Forest gain in northern China during 2007-2017 was mainly occurred in the eastern and southern zones, and it may be caused by the implementation of several ecological projects, such as the TNSFP. However, forest gain occurred mostly in the areas with annual mean precipitation over $400 \mathrm{~mm}$ (i.e., humid and sub-humid areas); the forest coverage has no significant increase in the areas with annual mean precipitation less than $400 \mathrm{~mm}$ (i.e., arid and semi-arid areas). For example, Northeast China has a temperate monsoon climate and fertile resources. Forest cover has increased significantly in this region (Figure 9), which agreed with the previous study on the significant increase of vegetation cover in Northeast China [59]. The Beijing-Tianjin-Hebei region is the largest and most dynamic region in northern China with a temperate continental climate. Forest cover has grown significantly in this region (Figure 9). In Shaanxi and Shanxi, forest cover has grown significantly (Figure 9), which agrees with previous researches on the Loess Plateau $[47,60]$.

Both natural and anthropic factors caused the forest loss in northern China. The forest loss could be likely due to deforestation. For example, Northeast China is the most important region for timber production in China. Due to poor management and excessive logging, the forest area in this region has been greatly reduced in recent years. Besides, natural environmental conditions could influence the survival of forest. In this study, a significant negative relationship between forest loss and annual mean precipitation (Figure 11) might indicate that the ratio of forest loss in the arid and semi-arid areas (i.e., areas with annual mean precipitation less than $400 \mathrm{~mm}$ ) was significantly greater than that in the humid and semi-humid areas in northern China. The higher rate of forest loss drylands was likely caused by many reasons, such as water stress, unreasonable planting methods, the impact of pests and diseases, human activities, etc. It should be noted that precipitation frequency and the length of drought period were not included in this study; they could also contribute to the forest loss. Clearly, forest growth requires suitable water conditions. Previous studies have shown that forest coverage is relatively high in areas with the annual mean precipitation above $400 \mathrm{~mm}$, and the value is mostly below $10 \%$ in areas with annual mean precipitation less than $400 \mathrm{~mm}$ [61]. Moreover, some studies showed that in areas with the annual mean precipitation less than $400 \mathrm{~mm}$, soil moisture is often insufficient for tree planting due to low annual precipitation that leads to largescale mortality of plantations in drought years $[62,63]$. Most of the trees planted in the TNSFP are poplars [64], which have high water requirements [13]. Harsh environmental conditions in the arid and semi-arid areas of northern China are insufficient to maintain poplars. The principal objective of the TNSFP is to increase the forest coverage and decrease wind erosion. In the early stages of the project, trees were planted on a large scale in arid and semi-arid areas, and they consumed large amounts of available soil moisture, which resulted in water scarcity [11].

\subsection{Implication of the PALSAR/Landsat-Based Forest Maps for Forest Management in Northern China}

In the context of ecological engineering, the overall forest area in northern China showed a substantial expansion in the last ten years, which was likely related to the TNSFP activity. Moreover, it should be noted that the forest loss rate exceeds $35 \%$ in areas where the annual mean precipitation is less than $400 \mathrm{~mm}$ (Figure 10f). That is to say, in the arid 
and sub-arid areas of northern China, forest coverage rate is low and forest loss rate is high. The significant negative relationship between forest loss and annual mean precipitation (Figure 11) also confirmed the risk of tree planting in arid and semi-arid areas. Besides, some studies have shown that in the context of global warming, arid regions are becoming increasingly arid, and humid regions are becoming increasingly humid [65-67]. Due to the increase in atmospheric water demand caused by climate warming, drought pressure has increased, and the growth of forests declines in semi-arid area [68]. Therefore, it is important to take account into the potential influence of natural environments on the effectiveness of forest restoration. In future research, we will focus specifically on the actual polygons of afforested areas to assess the afforestation effectiveness of TNSFP more accurately. In addition, future ecological engineering could focus on natural vegetation restoration on a large scale that might avoid excessive investment and obtain optimal returns [59].

\section{Conclusions}

Accurate information on the forest spatial-temporal changes and its association with natural environmental conditions are critical for supporting forest management. Taking northern China as an example, this study generated the $30 \mathrm{~m}$ forest maps from 2007 to 2017 by integrating the Landsat TM/ETM+/OLI and PALSAR/PALSAR-2 data. Our results (namely, PALSAR/Landsat-based forest maps) were qualitatively and quantitatively evaluated based on the ground samples and the comparison with other existing forest products (i.e., GlobeLand30, FROM-GLC, NLCD-China, and JAXA F/NF). The spatial-temporal analyses of forests showed a substantial forest expansion from $316,898 \pm 34,537 \mathrm{~km}^{2}$ in 2007 to $384,568 \pm 35,855 \mathrm{~km}^{2}$ in 2017 in the central and eastern areas. We found a higher forest loss rate $(35 \%)$ in the arid and semi-arid regions (i.e., areas with the annual mean precipitation less than $400 \mathrm{~mm}$ ) comparing to that $(25 \%)$ in the humid areas (i.e., areas with the annual mean precipitation more than $400 \mathrm{~mm}$ ). The significant negative relationship between annual mean precipitation and the ratio of forest loss indicates that the ratio of forest loss in the arid and semi-arid areas was significantly greater than of the humid and semi-humid areas in northern China. Our results indicate that the PALSAR/Landsat-based forest maps offer the details in forest pattern, and the association between precipitation zones and forest changes from 2007 to 2017 suggested that the suitability of tree planting should be considered in future forest management.

Supplementary Materials: The following are available online at https:/ / www.mdpi.com/2072-429 2/13/4/543/s1, Figure S1: Cumulative percentage of good observations derived from Landsat 5/7/8/ data covering the study area, Figure S2: Spatial distribution of forest gain, forest loss, stable forest and stable non-forest in northern China from 2015 to 2017, Figure S3: Spatial distribution of forest cover in northern China from 2007 to 2017. The results for 2011-2014 were unavailable due to the absence of PALSAR/PALSAR-2 data in this period, Table S1: Confusion matrix for the PALSAR/Landsatbased forest map in 2010. Accuracy measures are presented with a 95\% confidence interval, Table S2: Confusion matrix for the GlobeLand30 forest map in 2010. Accuracy measures are presented with a 95\% confidence interval, Table S3: Confusion matrix for the FROM-GLC forest map in 2010. Accuracy measures are presented with a 95\% confidence interval, Table S4: Confusion matrix for the NLCD-China forest map in 2010. Accuracy measures are presented with a 95\% confidence interval, Table S5: Confusion matrix for the JAXA forest map in 2010. Accuracy measures are presented with a $95 \%$ confidence interval.

Author Contributions: Conceptualization, H.L., F.X., and J.D.; data curation, H.L. and H.Z.; funding acquisition, F.X. and J.D.; methodology, H.L., N.Y., and J.D.; writing —original draft preparation, H.L. and J.D.; writing-review and editing, X.X., J.D., Z.L., N.Y., B.C., Y.Q., X.X., and Y.Z. All authors have read and agreed to the published version of the manuscript.

Funding: This research was funded by the Strategic Priority Research Program (XDA19040301) and Key Research Program of Frontier Sciences (QYZDB-SSW-DQC005) of Chinese Academy of Sciences (CAS), National Natural Science Foundation of China (61772078), Key R\&D Program of Beijing (D171100001817003). 
Institutional Review Board Statement: Not applicable.

Informed Consent Statement: Not applicable.

Data Availability Statement: Data sharing not applicable.

Acknowledgments: The authors thank everyone who made valuable suggestions for this article. In addition, we would like to give special thanks to the following students for their great contribution to the visual interpretation of the samples: Jinming Liu, Xinyue Yang, Yayan Cui, Tongze Guo, and Xuezhen Hou.

Conflicts of Interest: The authors declare no conflict of interest.

\section{References}

1. Chen, C.; Park, T.; Wang, X.; Piao, S.; Xu, B.; Chaturvedi, R.K.; Fuchs, R.; Brovkin, V.; Ciais, P.; Fensholt, R.; et al. China and India lead in greening of the world through land-use management. Nat. Sustain. 2019, 2, 122-129. [CrossRef] [PubMed]

2. Huang, S.; Kong, J. Assessing land degradation dynamics and distinguishing human-induced changes from climate factors in the Three-North Shelter forest region of China. ISPRS Int. J. Geo Inf. 2016, 5, 158. [CrossRef]

3. Lü, Y.; Zhang, L.; Feng, X.; Zeng, Y.; Fu, B.; Yao, X.; Li, J.; Wu, B. Recent ecological transitions in China: Greening, browning and influential factors. Sci. Rep. 2015, 5, 8732. [CrossRef] [PubMed]

4. Foley, J.A.; DeFries, R.; Asner, G.P.; Barford, C.; Bonan, G.; Carpenter, S.R.; Chapin, F.S.; Coe, M.T.; Daily, G.C.; Gibbs, H.K.; et al. Global Consequences of Land Use. Science 2005, 309, 570-574. [CrossRef] [PubMed]

5. Zhu, J.; Zheng, X.; Wang, G.; Wu, B.; Liu, S.; Yan, C.; Li, Y.; Sun, Y.; Yan, Q.; Zeng, Y.J.B. Assessment of the world largest afforestation program: Success, failure, and future directions. bioRxiv 2017, 105619. [CrossRef]

6. Qiu, B.; Chen, G.; Tang, Z.; Lu, D.; Wang, Z.; Chen, C.; Sensing, R. Assessing the Three-North Shelter Forest Program in China by a novel framework for characterizing vegetation changes. ISPRS J. Photogramm. Remote Sens. 2017, 133, 75-88. [CrossRef]

7. Duan, H.; Yan, C.; Tsunekawa, A.; Song, X.; Li, S.; Xie, J. Assessing vegetation dynamics in the Three-North Shelter Forest region of China using AVHRR NDVI data. Environ. Earth Sci. 2011, 64, 1011-1020. [CrossRef]

8. State Forestry and Grassland Ad-ministration. 40-Year Comprehensive Evaluation Report of the Three-North Shelterbelt Forest Program; State Forestry and Grassland Administration: Beijing, China, 2018.

9. Niu, Q.; Xiao, X.; Zhang, Y.; Qin, Y.; Dang, X.; Wang, J.; Zou, Z.; Doughty, R.; Brandt, M.; Tong, X.; et al. Ecological engineering projects increased vegetation cover, production, and biomass in semiarid and subhumid Northern China. Land Degrad. Dev. 2019, 30, 1620-1631. [CrossRef]

10. He, B.; Chen, A.; Wang, H.; Wang, Q. Dynamic Response of Satellite-Derived Vegetation Growth to Climate Change in the Three North Shelter Forest Region in China. Remote Sens. 2015, 7, 9998-10016. [CrossRef]

11. Wang, X.; Zhang, C.; Hasi, E.; Dong, Z. Has the Three Norths Forest Shelterbelt Program solved the desertification and dust storm problems in arid and semiarid China? J. Arid. Environ. 2010, 74, 13-22. [CrossRef]

12. Song, L.-N.; Zhu, J.-J.; Yan, Q.-L. Review on the shelter forest decline. Chin. J. Ecol. 2009, 28, 1684-1690.

13. Cao, S. Why Large-Scale Afforestation efforts in China Have Failed to Solve the Desertification Problem; ACS Publications: Washington, DC, USA, 2008.

14. Loveland, T.R.; Reed, B.C.; Brown, J.F.; Ohlen, D.O.; Zhu, Z.; Yang, L.; Merchant, J.W. Development of a global land cover characteristics database and IGBP DISCover from $1 \mathrm{~km}$ AVHRR data. Int. J. Remote Sens. 2000, 21, 1303-1330. [CrossRef]

15. Hansen, M.C.; DeFries, R.S. Detecting Long-term Global Forest Change Using Continuous Fields of Tree-Cover Maps from 8-km Advanced Very High Resolution Radiometer (AVHRR) Data for the Years 1982? Ecosystems 2004, 7, 695-716. [CrossRef]

16. Hansen, M.C.; Stehman, S.V.; Potapov, P.V.; Loveland, T.R.; Townshend, J.R.; DeFries, R.S.; Pittman, K.W.; Arunarwati, B.; Stolle, F.; Steininger, M.K.; et al. Humid tropical forest clearing from 2000 to 2005 quantified by using multitemporal and multiresolution remotely sensed data. Proc. Natl. Acad. Sci. USA 2008, 105, 9439-9444. [CrossRef] [PubMed]

17. Hansen, M.C.; DeFries, R.S.; Townshend, J.R.; Carroll, M.; DiMiceli, C.; Sohlberg, R.A. Global percent tree cover at a spatial resolution of $500 \mathrm{~m}$ : First results of the MODIS vegetation continuous fields algorithm. Earth Interact. 2003, 7, 1-15. [CrossRef]

18. Friedl, M.A.; Sulla-Menashe, D.; Tan, B.; Schneider, A.; Ramankutty, N.; Sibley, A.; Huang, X. MODIS Collection 5 global land cover: Algorithm refinements and characterization of new datasets. Remote Sens. Environ. 2010, 114, 168-182. [CrossRef]

19. Kim, D.-H.; Sexton, J.O.; Noojipady, P.; Huang, C.; Anand, A.; Channan, S.; Feng, M.; Townshend, J.R. Global, Landsat-based forest-cover change from 1990 to 2000. Remote Sens. Environ. 2014, 155, 178-193. [CrossRef]

20. Hansen, M.C.; Potapov, P.V.; Moore, R.; Hancher, M.; Turubanova, S.A.; Tyukavina, A.; Thau, D.; Stehman, S.; Goetz, S.J.; Loveland, T.R.; et al. High-resolution global maps of 21st-century forest cover change. Science 2013, 342, 850-853. [CrossRef]

21. Chen, B.; Xiao, X.; Li, X.; Pan, L.; Doughty, R.; Ma, J.; Dong, J.; Qin, Y.; Zhao, B.; Wu, Z.; et al. A mangrove forest map of China in 2015: Analysis of time series Landsat 7/8 and Sentinel-1A imagery in Google Earth Engine cloud computing platform. ISPRS J. Photogramm. Remote Sens. 2017, 131, 104-120. [CrossRef]

22. Midekisa, A.; Holl, F.; Savory, D.J.; Andrade-Pacheco, R.; Gething, P.W.; Bennett, A.; Sturrock, H.J.W. Mapping land cover change over continental Africa using Landsat and Google Earth Engine cloud computing. PLoS ONE 2017, 12, e0184926. [CrossRef] 
23. Woodcock, C.E.; Allen, R.; Anderson, M.; Belward, A.; Bindschadler, R.; Cohen, W.; Gao, F.; Goward, S.N.; Helder, D.; Helmer, E.; et al. Free Access to Landsat Imagery. Science 2008, 320, 1011a. [CrossRef] [PubMed]

24. Townshend, J.R.; Masek, J.G.; Huang, C.; Vermote, E.F.; Gao, F.; Channan, S.; Sexton, J.O.; Feng, M.; Narasimhan, R.; Kim, D.; et al. Global characterization and monitoring of forest cover using Landsat data: Opportunities and challenges. Int. J. Digit. Earth 2012, 5, 373-397. [CrossRef]

25. Jin, S.; Yang, L.; Danielson, P.; Homer, C.G.; Fry, J.; Xian, G. A comprehensive change detection method for updating the National Land Cover Database to circa. Remote Sens. Environ. 2013, 132, 159-175. [CrossRef]

26. Homer, C.; Dewitz, J.; Yang, L.; Jin, S.; Danielson, P.; Xian, G.; Coulston, J.; Herold, N.; Wickham, J.; Megown, K.; et al. Completion of the 2011 National Land Cover Database for the conterminous United States-representing a decade of land cover change information. Photogramm. Eng. Remote Sens. 2015, 81, 345-354.

27. Asner, G.P. Cloud cover in Landsat observations of the Brazilian Amazon. Int. J. Remote Sens. 2001, 22, 3855-3862. [CrossRef]

28. Bastin, J.-F.; Berrahmouni, N.; Grainger, A.; Maniatis, D.; Mollicone, D.; Moore, R.; Patriarca, C.; Picard, N.; Sparrow, B.; Abraham, E.M.; et al. The extent of forest in dryland biomes. Science 2017, 356, 635-638. [CrossRef]

29. Shimada, M. Long-term stability of L-band normalized radar cross section of Amazon rainforest using the JERS-1 SAR. Can. J. Remote Sens. 2005, 31, 132-137. [CrossRef]

30. Thapa, R.B.; Itoh, T.; Shimada, M.; Watanabe, M.; Takeshi, M.; Shiraishi, T. Evaluation of ALOS PALSAR sensitivity for characterizing natural forest cover in wider tropical areas. Remote Sens. Environ. 2014, 155, 32-41. [CrossRef]

31. Reiche, J.; Verbesselt, J.; Hoekman, D.H.; Herold, M. Fusing Landsat and SAR time series to detect deforestation in the tropics. Remote Sens. Environ. 2015, 156, 276-293. [CrossRef]

32. Shimada, M.; Itoh, T.; Motooka, T.; Watanabe, M.; Shiraishi, T.; Thapa, R.; Lucas, R. New global forest/non-forest maps from ALOS PALSAR data (2007-2010). Remote Sens. Environ. 2014, 155, 13-31. [CrossRef]

33. Pantze, A.; Santoro, M.; Fransson, J.E. Change detection of boreal forest using bi-temporal ALOS PALSAR backscatter data. Remote Sens. Environ. 2014, 155, 120-128. [CrossRef]

34. Dong, J.; Xiao, X.; Sheldon, S.; Biradar, C.; Duong, N.D.; Hazarika, M.K. A comparison of forest cover maps in Mainland Southeast Asia from multiple sources: PALSAR, MERIS, MODIS and FRA. Remote Sens. Environ. 2012, 127, 60-73. [CrossRef]

35. Motohka, T.; Shimada, M.; Uryu, Y.; Setiabudi, B. Using time series PALSAR gamma nought mosaics for automatic detection of tropical deforestation: A test study in Riau, Indonesia. Remote Sens. Environ. 2014, 155, 79-88. [CrossRef]

36. Jin, H.; Mountrakis, G.; Stehman, S.V.; Sensing, R. Assessing integration of intensity, polarimetric scattering, interferometric coherence and spatial texture metrics in PALSAR-derived land cover classification. ISPRS J. Photogramm. Remote Sens. 2014, 98, 70-84.

37. Whittle, M.; Quegan, S.; Uryu, Y.; Stüewe, M.; Yulianto, K. Detection of tropical deforestation using ALOS-PALSAR: A Sumatran case study. Remote Sens. Environ. 2012, 124, 83-98. [CrossRef]

38. Qin, Y.; Xiao, X.; Wang, J.; Dong, J.; Ewing, K.; Hoagland, B.; Hough, D.J.; Fagin, T.D.; Xiao, X.; Geissler, G.L.; et al. Mapping Annual Forest Cover in Sub-Humid and Semi-Arid Regions through Analysis of Landsat and PALSAR Imagery. Remote Sens. 2016, 8, 933. [CrossRef]

39. Chen, B.; Xiao, X.; Ye, H.; Ma, J.; Doughty, R.; Li, X.; Zhao, B.; Wu, Z.; Sun, R.; Dong, J.; et al. Mapping Forest and Their Spatial-Temporal Changes From 2007 to 2015 in Tropical Hainan Island by Integrating ALOS/ALOS-2 L-Band SAR and Landsat Optical Images. IEEE J. Sel. Top. Appl. Earth Obs. Remote Sens. 2018, 3, 852-867. [CrossRef]

40. Zhu, Z.; Liu, S.; Di, X. Desertification and Its Control in China; Science Press: Beijing, China, 1989; Volume 54, pp. 5-20.

41. Shimada, M.; Ohtaki, T.; Sensing, R. Generating large-scale high-quality SAR mosaic datasets: Application to PALSAR data for global monitoring. IEEE J. Sel. Top. Appl. Earth Obs. Remote Sens. 2010, 3, 637-656. [CrossRef]

42. Rosenqvist, A.; Shimada, M.; Ito, N.; Watanabe, M.; Sensing, R. ALOS PALSAR: A Pathfinder Mission for Global-Scale Monitoring of the Environment. IEEE Trans. Geosci. Remote Sens. 2007, 45, 3307-3316. [CrossRef]

43. Shimada, M.; Isoguchi, O.; Tadono, T.; Isono, K.; Sensing, R. PALSAR Radiometric and Geometric Calibration. IEEE Trans. Geosci. Remote Sens. 2009, 47, 3915-3932. [CrossRef]

44. Parker, J.A.; Kenyon, R.V.; Troxel, D.E. Comparison of Interpolating Methods for Image Resampling. IEEE Trans. Med. Imaging 1983, 2, 31-39. [CrossRef] [PubMed]

45. Foga, S.; Scaramuzza, P.L.; Guo, S.; Zhu, Z.; Dilley, R.D.; Beckmann, T.; Schmidt, G.L.; Dwyer, J.L.; Hughes, M.J.; Laue, B. Cloud detection algorithm comparison and validation for operational Landsat data products. Remote Sens. Environ. 2017, 194, 379-390. [CrossRef]

46. FAO. Global Forest Resources Assessment 2010: Main Report; Food and Agriculture Organization of the United Nations (FAO): Rome, Italy, 2010.

47. Zhou, H.; Xu, F.; Dong, J.; Yang, Z.; Zhao, G.; Zhai, J.; Qin, Y.; Xiao, X. Tracking Reforestation in the Loess Plateau, China after the "Grain for Green" Project through Integrating PALSAR and Landsat Imagery. Remote Sens. 2019, 11, 2685. [CrossRef]

48. Yang, Z.; Dong, J.; Qin, Y.; Ni, W.; Zhao, G.; Chen, W.; Chen, B.; Kou, W.; Wang, J.; Xiao, X. Integrated Analyses of PALSAR and Landsat Imagery Reveal More Agroforests in a Typical Agricultural Production Region, North China Plain. Remote Sens. 2018, 10, 1323. [CrossRef]

49. Gamon, J.A.; Field, C.B.; Goulden, M.L.; Griffin, K.L.; Hartley, A.E.; Joel, G.; Penuelas, J.; Valentini, R. Relationships Between NDVI, Canopy Structure, and Photosynthesis in Three Californian Vegetation Types. Ecol. Appl. 1995, 5, 28-41. [CrossRef] 
50. Olofsson, P.; Foody, G.M.; Herold, M.; Stehman, S.V.; Woodcock, C.E.; Wulder, M.A. Good practices for estimating area and assessing accuracy of land change. Remote Sens. Environ. 2014, 148, 42-57. [CrossRef]

51. Mayaux, P.; Eva, H.; Gallego, J.; Strahler, A.H.; Herold, M.; Agrawal, S.; Naumov, S.; De Miranda, E.E.; Di Bella, C.M.; Ordoyne, C.; et al. Validation of the global land cover 2000 map. IEEE Trans. Geosci. Remote Sens. 2006, 44, 1728-1739. [CrossRef]

52. Yang, Y.; Xiao, P.; Feng, X.; Li, H.; Sensing, R. Accuracy assessment of seven global land cover datasets over China. ISPRS J. Photogramm. Remote Sens. 2017, 125, 156-173. [CrossRef]

53. Bey, A.; Sánchez-Paus Díaz, A.; Maniatis, D.; Marchi, G.; Mollicone, D.; Ricci, S.; Bastin, J.-F.; Moore, R.; Federici, S.; Rezende, M.; et al. Collect Earth: Land Use and Land Cover Assessment through Augmented Visual Interpretation. Remote Sens. 2016, 8, 807. [CrossRef]

54. Gong, P.; Wang, J.; Yu, L.; Zhao, Y.; Zhao, Y.; Liang, L.; Niu, Z.; Huang, X.; Fu, H.; Liu, S.; et al. Finer resolution observation and monitoring of global land cover: First mapping results with Landsat TM and ETM+ data. Int. J. Remote Sens. 2012, 34, 2607-2654. [CrossRef]

55. Chen, J.; Chen, J.; Liao, A.; Cao, X.; Chen, L.; Chen, X.; He, C.; Han, G.; Peng, S.; Lu, M.; et al. Global land cover mapping at 30m resolution: A POK-based operational approach. ISPRS J. Photogramm. Remote Sens. 2015, 103, 7-27. [CrossRef]

56. Liu, J.; Liu, M.; Tian, H.; Zhuang, D.; Zhang, Z.; Zhang, W.; Tang, X.; Deng, X. Spatial and temporal patterns of China's cropland during 1990-2000: An analysis based on Landsat TM data. Remote Sens. Environ. 2005, 98, 442-456. [CrossRef]

57. Liu, J.; Kuang, W.; Zhang, Z.; Xu, X.; Qin, Y.; Ning, J.; Zhou, W.; Zhang, S.; Li, R.; Yan, C.; et al. Spatiotemporal characteristics, patterns, and causes of land-use changes in China since the late 1980s. J. Geogr. Sci. 2014, 24, 195-210. [CrossRef]

58. Sexton, J.O.; Noojipady, P.; Song, X.-P.; Feng, M.; Song, D.-X.; Kim, D.-H.; Anand, A.; Huang, C.; Channan, S.; Pimm, S.L.; et al. Conservation policy and the measurement of forests. Nat. Clim. Chang. 2016, 6, 192-196. [CrossRef]

59. Wang, F.; Pan, X.; Gerlein-Safdi, C.; Cao, X.; Wang, S.; Gu, L.; Wang, D.; Lu, Q. Vegetation restoration in N orthern China: A contrasted picture. Land Degrad. Dev. 2020, 31, 669-676. [CrossRef]

60. Feng, X.; Fu, B.; Piao, S.; Wang, S.; Ciais, P.; Zeng, Z.; Lü, Y.; Zeng, Y.; Li, Y.; Jiang, X.; et al. Revegetation in China's Loess Plateau is approaching sustainable water resource limits. Nat. Clim. Chang. 2016, 6, 1019-1022. [CrossRef]

61. Hansen, M.C.; Townshend, J.R.G.; DeFries, R.S.; Carroll, M. Estimation of tree cover using MODIS data at global, continental and regional/local scales. Int. J. Remote Sens. 2005, 26, 4359-4380. [CrossRef]

62. Wang, G.; Liu, G.; Zhou, S. Research Advance of Soil Dried Layer on Loess Plateau. J. Soil Water Conserv. 2003, 6, 156-159.

63. Cui, X.; Sui, P.; Xie, G.; Gao, W. Soil Water Effect and Productivity in Poplar and Wheat-Corn Agroforestry Systems. Sci. Agric. Sin. 2006, 39, 758-763.

64. Su, Y. Review of 25-year's result of three northern regions shelter forest system project, China. China Sci. Cult. 2004, 3, 42-44.

65. Feng, H.; Zhang, M. Global land moisture trends: Drier in dry and wetter in wet over land. Sci. Rep. 2015, 5, 18018. [CrossRef] [PubMed]

66. Chou, C.; Neelin, J.D.; Chen, C.-A.; Tu, J.-Y. Evaluating the "Rich-Get-Richer" Mechanism in Tropical Precipitation Change under Global Warming. J. Clim. 2009, 22, 1982-2005. [CrossRef]

67. Chou, C.; Chiang, J.C.H.; Lan, C.-W.; Chung, C.-H.; Liao, Y.-C.; Lee, C.-J. Increase in the range between wet and dry season precipitation. Nat. Geosci. 2013, 6, 263-267. [CrossRef]

68. Liu, H.; Park Williams, A.; Allen, C.D.; Guo, D.; Wu, X.; Anenkhonov, O.A.; Liang, E.; Sandanov, D.V.; Yin, Y.; Qi, Z.; et al. Rapid warming accelerates tree growth decline in semi-arid forests of Inner Asia. Glob. Chang. Biol. 2013, 19, 2500-2510. [CrossRef] [PubMed] 